
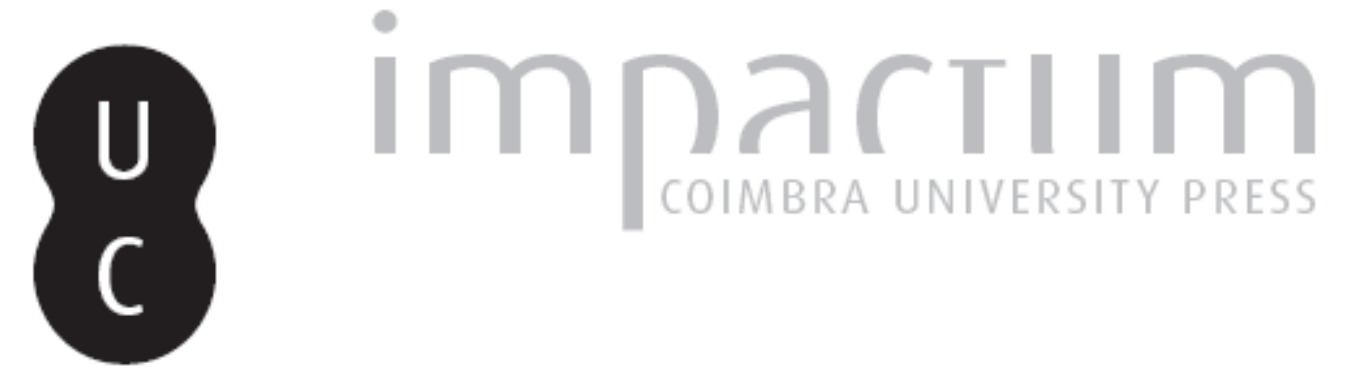

\title{
Desinstituição e desobediência civil: entre o estado de exceção e a democracia radical
}

Autor(es): $\quad$ Matos, Andityas Soares de Moura Costa

Publicado por: Imprensa da Universidade de Coimbra, Instituto de Estudos Filosóficos

URL persistente:

URI:http://hdl.handle.net/10316.2/42145

DOI:

DOI:http://dx.doi.org/10.14195/0872-0851_51_1

Accessed : $\quad$ 26-Apr-2023 00:24:29

A navegação consulta e descarregamento dos títulos inseridos nas Bibliotecas Digitais UC Digitalis, UC Pombalina e UC Impactum, pressupõem a aceitação plena e sem reservas dos Termos e Condições de Uso destas Bibliotecas Digitais, disponíveis em https://digitalis.uc.pt/pt-pt/termos.

Conforme exposto nos referidos Termos e Condições de Uso, o descarregamento de títulos de acesso restrito requer uma licença válida de autorização devendo o utilizador aceder ao(s) documento(s) a partir de um endereço de IP da instituição detentora da supramencionada licença.

Ao utilizador é apenas permitido o descarregamento para uso pessoal, pelo que o emprego do(s) título(s) descarregado(s) para outro fim, designadamente comercial, carece de autorização do respetivo autor ou editor da obra.

Na medida em que todas as obras da UC Digitalis se encontram protegidas pelo Código do Direito de Autor e Direitos Conexos e demais legislação aplicável, toda a cópia, parcial ou total, deste documento, nos casos em que é legalmente admitida, deverá conter ou fazer-se acompanhar por este aviso.

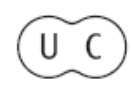




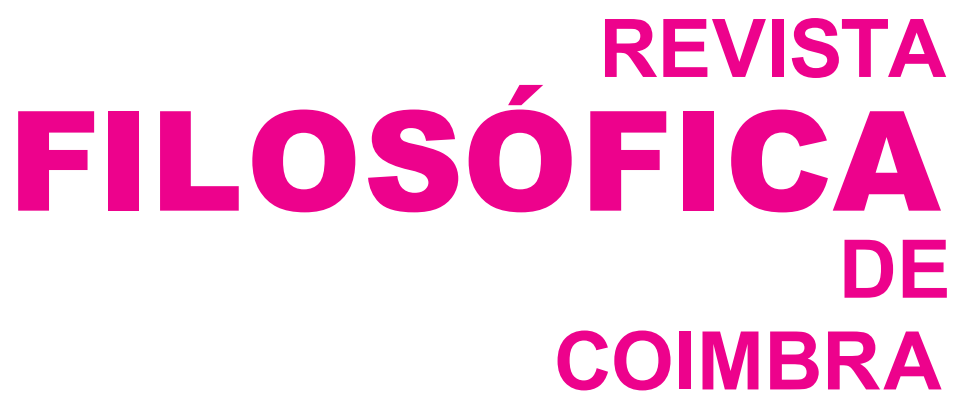

vol. 26 - número 51 - março 2017

vol. 26 - número 51 - março 2017

Fundação Eng. António de Almeida

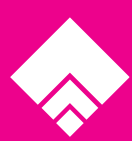




\title{
DESINSTITUIÇÃO E DESOBEDIÊNCIA CIVIL: ENTRE O ESTADO DE EXCEÇÃO E A DEMOCRACIA RADICAL ${ }^{1}$
}

\author{
DES-INSTITUTING POWER AND CIVIL DISOBEDIENCE: \\ BETWEEN THE STATE OF EXCEPTION AND RADICAL DEMOCRACY
}

ANDITYAS SOARES DE MOURA COSTA MATOS ${ }^{2}$

Resumo: Neste artigo pretende-se apresentar uma nova leitura da desobediência civil, com o objetivo de assim revelar suas potencialidades para a construção de uma democracia radical. Para tanto, na seção 1 são revisitadas as duas principais tradições - liberalismo político e constitucionalismo - que se dedicaram a pensar a desobediência civil no último século, indicando seus avanços e limitações. Na seção 2 fundamenta-se a hipótese segundo a qual vivemos hoje sob um estado de exceção econômico permanente, razão pela qual os entendimentos convencionais acerca da desobediência civil - que a veem ora como mero mecanismo de pressão política, ora como dispositivo de autocorreção do sistema político-jurídico - se mostram insuficientes diante do quadro paradigmático da pós-democracia. Por fim, após discutir as diferenças entre poder constituinte e poder desinstituinte, afirmando que a desobediência civil se exerce em uma relação na qual ambos estão ativados (seção 3), o trabalho conclui com a indicação das características e formas de ação da desobediência civil entendida enquanto manifestação do poder constituinte/desinstituinte.

Palavras-chave: Desobediência civil, estado de exceção econômico, poder constituinte, poder desinstituinte, democracia radical.

1 Este trabalho foi realizado durante meu estágio pós-doutoral na Facultat de Dret de la Universitat de Barcelona (Espanya), com bolsa da CAPES, Fundação à qual agradeço pela excelência e seriedade no trato com a pesquisa e a produção de novos conhecimentos. Agradeço também aos Professores Doutores José Antonio Estévez Araujo, Antonio Giménez Merino, Antonio Madrid Pérez e Francis García Collado pela acolhida em Barcelona e pelas constantes e enriquecedoras trocas intelectuais.

2 Graduado em Direito, Mestre em Filosofia do Direito e Doutor em Direito e Justiça pela Faculdade de Direito e Ciências do Estado da Universidade Federal de Minas Gerais (UFMG). Doutorando em Filosofia pela Universidade de Coimbra (Portugal). Professor Adjunto de Filosofia do Direito e disciplinas afins na Faculdade de Direito e Ciências do Estado da UFMG.E-mails: vergiliopublius@hotmail.com e andityas@ufmg.br 
Abstract: In this paper, we intend to present a new reading of the civil disobedience, in order to reveal its potentialities to build a radical democracy. In section 1 the two main traditions dedicated to think civil disobedience in the last century - political liberalism and constitutionalism - are revisited, and their advances and limitations are indicated. Section 2 substantiates the hypothesis that we live nowadays in a permanent state of economic exception, thus explaining why the conventional understandings regarding civil disobedience - sometimes seen as a mere political pressure mechanism, sometimes as a self-correcting device of the political-legal system - are insufficient before the paradigmatic framework of post-democracy. Stating that civil disobedience is triggered by the relationship between constituent power and des-instituting power (section 3), whose differences are finally discussed, the article gives an indication of the features and forms of civil disobedience's action understood as a manifestation of the constituent/des-instituting power.

Keywords: Civil disobedience, permanent state of economic exception, constituent power, des-instituting power, radical democracy.
Resumen: Este artículo tiene como objetivo presentar una nueva lectura de la desobediencia civil, con el fin de revelar así su potencial para construir una democracia radical. Para ello, en la primera sección se revisan las dos tradiciones principales - el liberalismo político y el constitucionalismo - que se dedicaron a pensar en la desobediencia civil en el siglo pasado, señalando así tanto sus progresos como sus limitaciones. En la segunda sección se fundamenta la hipótesis según la cual hoy vivimos en un estado de excepción económico permanente, por lo que la comprensión convencional sobre la desobediencia civil - que en ocasiones es vista como un mero mecanismo de presión política y otras veces como un dispositivo de auto-corrección del sistema político-jurídico - son insuficientes ante el marco paradigmático de la post-democracia. Finalmente, tras discutir las diferencias entre poder constituyente y poder desinstituyente, afirmando que la desobediencia civil se ejerce en una relación en la que ambos están activados (tercera sección), el trabajo concluye con la indicación de las características y formas de acción de la desobediencia civil entendida como manifestación del poder constituyente/ desinstituyente

Palabras clave: Desobediencia civil, estado de excepción económico, poder constituyente, poder desinstituyente, democracia radical. 


\section{Introdução}

Há pelos menos duas vertentes tradicionais que tentam compreender a natureza da desobediência civil: o liberalismo e o constitucionalismo. Não obstante o fato de o constitucionalismo representar um inegável avanço em relação à leitura puramente liberal da desobediência civil, minha hipótese de trabalho é que a compreensão da desobediência civil precisa ser radicalizada, de modo a compreendê-la não enquanto expressão constitucional do poder constituído, mas antes como manifestação permanente da relação entre poder constituinte e poder desinstituinte ${ }^{3}$. Sem esse salto teórico e prático a desobediência civil estará condenada a ser mais um dos mecanismos jurídicos que, em sua ineficácia, não são hoje capazes de oferecer vias alternativas à situação de exceção econômica permanente em que vivemos. No entanto, antes de discutir tal tema, é necessário percorrer rapidamente os principais momentos da conceituação da ideia de desobediência civil, bem como suas diversas fundamentações teóricas produzidas nos marcos das duas tradições - liberal e constitucionalista - que a pensaram no último século - objeto da seção 1 deste texto -, frisando desde já que a divisão entre tais matrizes teóricas possui validade apenas didática, eis que muitas vezes se confundem e complementam, tendo em vista o fato óbvio de que o constitucionalismo nasce e se desenvolve a partir de uma visão liberal do direito e da política.

Caso abandonemos a posição ingênua segundo a qual há uma essência libertária ou democrática nos atuais Estados de Direito que se encontra colonizada ou bloqueada pelas forças neoliberais dos mercados e das finanças globais, e entendermos que nos encontramos em um novo momento histórico paradigmático no qual tanto o projeto político liberal quanto o projeto econômico socialdemocrata falharam, abre-se possibilidade de pensar a desobediência civil como uma das expressões radicais do poder constituinte, apontando para uma crítica e uma reação geral ao sistema da exceção permanente. Para investigar tal hipótese, é preciso verificar a tese segundo a qual vivemos em um estado de exceção econômico permanente - tema da seção 2 -, bem como avaliar a dinâmica existente entre poder constituído, constituinte e desinstituinte - matéria da seção 3 -, indicando as possibilidades de se conceber a desobediência civil nesses três campos. O texto termina na quarta seção, na qual apresento uma proposta para a fundamentação da tese que me interessa defender, qual seja: em uma democracia radical - isto é, não

3 A palavra "desinstituinte" é um neologismo que utilizo com o fim de indicar que se trata de algo diferente de "destituinte", termo usado por Giorgio Agamben em L'uso dei corpi (Vicenza: Neri Pozza, 2015). A discussão aprofundada dessas diferenças ocupa a seção 3.2 deste artigo, bastando aqui explicitar apenas que com o termo "desinstituição" pretendo me referir à desconstrução de instituições do poder constituído. 
representativa - a única maneira de se compreender a desobediência civil é como manifestação do poder constituinte permanente da multidão, assumida como o verdadeiro sujeito do poder político.

Todavia, antes de iniciar a discussão, entendo relevante trazer já no início do debate a reflexão de Francisco Javier de Lucas Martín, para quem é preciso superar o discurso que entende ser perigosa e pejorativa toda crítica coerente e radical ao sistema de poderes constituídos, como é o caso daquela que aqui pretendo construir. De fato, vendo na desobediência civil uma crítica antissistema, muitos pretendem desqualificá-la e mesmo criminalizá-la, eis que não haveria lugar para esse tipo de manifestação em uma democracia institucionalizada. Ao contrário, segundo Lucas Martín, a desobediência civil é um dos instrumentos que torna possível frear o processo de desconstitucionalização de vários direitos, em especial os sociais. Só não enxergam tal realidade aqueles que, imbuídos de um "fundamentalismo democrático", acabam identificando legalidade e legitimidade, entendendo que a Constituição é um texto sagrado, interpretável apenas por uma minoria seleta de especialistas e que, portanto, pressupõe uma cidadania que, chamada apenas a depositar seu voto periodicamente nas urnas, se conforma enquanto maioria silenciosa ${ }^{4}$. Ainda segundo o autor, concepções assim

tornam-se presas desse "ódio à democracia", que na realidade parte do medo ao povo, tal como já estudado e denunciado por Jacques Rancière e que, por simplificar, resume-se numa atitude de suspeita e temor cada vez que o povo, isto é, a cidadania, parece tomar voz para recuperar aquilo que democracia significa frente ao misto de aristocracia cultural e oligarquia econômica [em que vivemos]. ${ }^{5}$

As recentes manifestações ao redor do globo - desde os movimentos da Primavera Árabe até às lutas dos indignados espanhóis e o Occupy Wall Street - demonstram a insatisfação dos cidadãos com sistemas político-jurídicos comprometidos com o mercado e o capital, envelhecidos e incapazes de absorver demandas mais amplas de inclusão social, em especial aquelas que dizem respeito ao direito à cidade e à moradia digna; à limitação do poder dos conglomerados econômicos; à tutela de interesses de grupos socialmente oprimidos (mulheres, negros, homossexuais, precarizados, subempregados, população de rua etc.); à consideração realista e resolutiva dos enormes problemas ambientais e climáticos que ameaçam a continuidade da vida no planeta; e à efetivação das garantias constitucionais relativas às liberdades civis constantemente limitadas por mecanismos de exceção.

${ }^{4}$ Francisco Javier de Lucas Martín, "Desobediência e democracia: a hora da cidadania", Revista da Faculdade de Direito da Universidade Federal de Goiás 1 (Janeiro/Junho 2013), vol. 37, 58-72, 58-59.

5 Lucas Martín, "Desobediência", 59. 
No Brasil, algumas dessas pautas se traduziram nas manifestações de junho de 2013, que inicialmente se voltaram para o questionamento da estrutura dos transportes públicos nas grandes metrópoles brasileiras. ${ }^{6} \mathrm{Nada}$ obstante, os temas que animaram esses movimentos rapidamente perderam a objetividade originária, tendo sido, em larga medida, apropriados e falseados pela mídia. Além disso, algumas ações passaram a se desenvolver em contextos nos quais não estava ausente a violência, patrocinada tanto por alguns grupos de manifestantes quanto por forças policiais, fato que determinou a demonização dos movimentos pelas mídias e seu progressivo esvaziamento. Nesse sentido, uma retomada da ideia de desobediência civil - cujo aspecto inegociável é seu resoluto caráter não-violento - associada a um aprofundamento de seu escopo - traduzido agora na vertente do poder constituinte permanente - é não apenas oportuna, mas urgente, dado que a principal função do pensamento político-jurídico democrático, em minha concepção, é oferecer não apenas vias de esclarecimento para práticas sociais emancipadoras e libertadoras, mas ao mesmo tempo compreendê-las, justificá-las e instigá-las. Aqui ainda vale a percepção de Guy Debord sobre o papel da filosofia: não se trata de fazer uma fogueira - o que, de resto, seria não só impossível, mas também presunçoso, típico daqueles que se autointitulam "filósofos-reis" -, e sim de jogar gasolina nas fogueiras já existentes, tornando novamente as ideias perigosas.

6 Minha intenção no presente trabalho não é analisar as manifestações de junho de 2013 no Brasil quanto a seu sentido político-filosófico - sempre disputado - e o perfil de seus participantes, tarefa que já realizei na obra Filosofia radical e utopias da inapropriabilidade. Uma aposta an-árquica na multidão (Belo Horizonte: Fino Traço, 2015). Nada obstante, o interessado pode ler com proveito alguns textos sobre o citado movimento. Para dados empíricos sobre a magnitude dos protestos, cf. Lincoln Secco, "As jornadas de junho", in: Cidades rebeldes. Passe livre e as manifestações que tomaram as ruas do Brasil, Ermínia Maricato et al., (São Paulo: Boitempo, 2013), 71-78. Sobre o perfil dos manifestantes, cf. Elena Judensnaider et al., Vinte centavos. A luta contra o aumento (São Paulo: Veneta, 2013). Para uma análise da dinâmica dos movimentos, cf. Maria da Glória Gohn, Manifestações de junho de 2013 no Brasil e praças dos indignados no mundo (Petrópolis: Vozes, 2014). Para a confrontação de várias leituras sociológicas, econômicas, políticas, jurídicas etc. dos acontecimentos de junho de 2013, cf. João Carlos Castellar (org.), Manifestações de junho de 2013. Avanços e retrocessos um ano depois (Rio de Janeiro: POD, 2015) e Rubens Figueiredo (org.), Junho de 2013. A sociedade enfrenta o Estado (Perdizes: Summus, 2014). 


\section{A desobediência civil entre o liberalismo político e o constitucio- nalismo ${ }^{7}$}

Entender a desobediência civil como expressão permanente do poder constituinte de uma democracia radical não é apenas uma proposta teórica inovadora de corte quase herético, mas também uma tomada de posição que traz importantes consequências para os movimentos e atores sociais que questionam a ordem capitalista. Como se verá a seguir, a localização da desobediência civil no campo do poder constituído ou no do poder constituinte se relaciona diretamente à sua fundamentação e justificação, bem como às limitações e potencialidades que o exercício prático da desobediência impõe aos atores sociais que dela lançam mão.

No que diz respeito à tradição do pensamento político-jurídico constituído, conforme indiquei em outro trabalho, ${ }^{8}$ a desobediência civil corresponde a uma postura política individual ou coletiva que, mediante ação organiza$d a$, consciente e não-violenta, contesta a validade de aspectos específicos do direito vigente. Assim, a desobediência civil não se identifica com uma simples revolta ou com a mera negativa de cumprimento de normas jurídicas. Trata-se de uma ação que busca transformar o direito sem, no entanto, utilizar para tanto mecanismos jurídico-institucionais. ${ }^{9}$ Segundo a doutrina tradicional que logo terei a oportunidade de problematizar, a desobediência civil não se identifica com a anarquia, que pregaria a ausência de qualquer ordem jurídica, e nem com a revolução, que objetivaria a integral transformação do direito e do Estado. Com efeito, a desobediência civil não se define pela negativa da ordem, do governo ou do direito, pretendendo antes questionar e resistir a uma específica ordem, a certo governo e a um particular direito que, por diversas razões, são tidos por injustos. ${ }^{10}$

7 O objetivo da presente seção é discutir a teoria da desobediência civil conforme constituída pelas duas tradições mais conhecidas e influentes do pensamento jurídico que lidaram com essa ideia, quais sejam, o liberalismo e o constitucionalismo, de maneira a perceber as limitações que a doutrina tradicional apresenta e assim preparar o terreno para uma nova proposta de compreensão da desobediência civil. Dessa feita, não pretendo neste trabalho discutir especificamente a prática da desobediência civil - ainda que eu utilize vários exemplos concretos para comprovar ou desconstruir argumentos teóricos -, tema que, por sua extensão e variabilidade, exige outro texto, o qual estou a preparar para publicação no próximo ano.

8 Andityas Soares de Moura Costa Matos, "A desobediência civil como direito fundamental”, Revista Del Rey Jurídica 16 (2006), ano 8, 56-58.

9 Giovanni Cosi, Saggio sulla disobbedienza civile. Storia e critica del dissenso in democrazia (Milano: Giuffrè, 1984); Teresa Serra, La disobbedienza civile. Una risposta alla crisi della democrazia? (Torino: Giappichelli, 2000) e Francesco Biondo, Tra diritto e morale. Saggio sulla disobbedienza civile (Torino: Giappichelli, 2008).

10 Barrington Moore Jr., Injustiça. As bases sociais da obediência e da revolta (São Paulo: Brasiliense, 1987). 
Embora muitos autores pretendam ver elementos de desobediência civil já no pensamento grego, em especial na célebre tragédia de Sófocles (Antígona) e no suicídio político de Sócrates, não há dúvidas de que o conceito só é afirmado em sua especificidade a partir da modernidade, como bem demonstrou Hannah Arendt. No mesmo sentido, ainda que a discussão sobre o direito de resistência - tema relacionado à desobediência civil, mas não idêntico - possa ser rastreada na obra de pensadores medievais como Tomás de Aquino, para quem seria lícito resistir às normas jurídico-positivas que não se adaptassem ao direito natural revelado pela Igreja, somente com o surgimento do Estado de Direito pôde-se pensar de maneira efetiva em estruturas de autocontrole capazes de evitar que a ordem jurídica se transformasse em um mecanismo de opressão da cidadania.

Algo como um esboço da ideia de desobediência civil compôs o rol original dos direitos fundamentais afirmados pelos revolucionários franceses de 1789. Lê-se no art. $2^{\circ}$ da Declaração dos Direitos do Homem e do Cidadão de 1789, primeiro diploma constitucional em que se encontra positivado o núcleo básico dos direitos fundamentais: "A finalidade de toda associação política é a conservação dos direitos naturais e imprescritíveis do homem. Esses direitos são a liberdade, a propriedade, a segurança e a resistência à opressão". Ora, a desobediência civil seria uma dessas formas de resistência à opressão. As razões pelas quais esse "direito de se resistir à opressão" não foi referenciado nas Constituições liberais do século XIX que se basearam na Declaração de 1789 são de ordem histórica e político-ideológica. Trata-se de um daqueles inumeráveis "esquecimentos" que o pensamento jurídico tradicional não aborda e finge não existir.

Nada obstante, para além do silêncio dos enunciados constitucionais, foi a prática que conferiu legitimidade à desobediência civil ao longo dos séculos XIX e XX. A ideia foi claramente enunciada no célebre ensaio de Henry David Thoreau de 1849, apresentando então nítido viés individualista, ${ }^{11}$ o que seria rapidamente superado pelos movimentos coletivos de luta por direitos encabeçados por figuras como Gandhi e Martin Luther King Jr. que, ademais, refletiram teoricamente sobre a natureza, a função e os problemas práticos relativos à desobediência civil. ${ }^{12}$ A partir dos anos 50 e 60 , em

11 Henry David Thoreau, "Civil disobedience", in: A yankee in Canada, with anti-slavery and reform papers, Henry David Thoreau, Boston: Ticknor and Fields, 1866, 123-151, acedido em 12 de outubro de 2014, https://archive.org/stream/ yankeeincanada00thorrich\#page/n7/mode/2up.

12 Cf. v.g. Mohandas Karamchand Gandhi, "Duty of disobeying laws", Indian opinion (7 and 14 September 1907); Mohandas Karamchand Gandhi, "For passive resisters", Indian Opinion (26 October 1907); Mohandas Karamchand Gandhi e Ronald Frederick Henry Duncan, Selected writings of Mahatma Gandhi (London: Faber and Faber, 1951); 
especial tendo em vista o movimento negro de luta pelos direitos civis nos Estados Unidos, se firma uma frutífera tradição liberal de interpretação da desobediência civil. Seus principais expoentes teóricos na contemporaneidade são Michael Walzer e John Rawls, que entendem a desobediência civil como uma forma de protesto individual ou coletiva, de tendência não-violenta, mas ilegal, que busca fazer pressão política para que sejam modificadas decisões ou normas tidas por injustas, seja porque são contrárias aos princípios superiores do ordenamento jurídico que integram, seja porque são atentatórias à consciência social de justiça. ${ }^{13}$

Embora a tradição do liberalismo político tenha sido importante para inserir a ideia de desobediência civil no debate contemporâneo (especialmente no cenário estadunidense), é preciso reconhecer que ela esvazia o sentido constitucional da desobediência civil ao concebê-la enquanto simples protesto ou medida de pressão política. Para o liberalismo, o objetivo da desobediência civil é, em última análise, propiciar a negociação com o Estado para assim se alcançar um acordo. ${ }^{14}$ Todavia, a noção de resistência à opressão na qual se funda a desobediência civil possui sede constitucional, como visto no art. $2^{\circ}$ da Declaração dos Direitos do Homem e do Cidadão. Vários Estados - tais como a Alemanha e Portugal ${ }^{15}$ - reconhecem expressamente em seus textos constitucionais mecanismos de resistência ao poder do Estado que podem ser interpretados como formas de desobediência civil. Assim, ao lado do liberalismo político, pode-se falar em outra vertente que dele deriva,

Vindra Varma, Gandhi. Poder, parceria e resistência (São Paulo: Palas Athena, 2002) e Martin Luther King Jr., A testament of hope. The essential writings and speeches of Martin Luther King Jr., edited by James Melvin Washington (New York: Harpercollins, 1991).

13 Ermanno Vitale, Defenderse del poder. Por una resistencia constitucional, trad. de Pedro Salazar Ugarte e Paula Sofía Vásquez Sánchez (Madrid: Trotta, 2010), 27-29.

14 Martin Luther King Jr., Por qué no podemos esperar, trad. de J. Romero Maura (Barcelona: Ayma, 1973), 109.

15 A Constituição da República Portuguesa de 1976 determina em seus artigos $7^{\circ} \mathrm{e}$ $21^{\circ}$ : "Artigo $7^{\circ}$ : Portugal reconhece o direito dos povos à autodeterminação e independência e ao desenvolvimento, bem como o direito à insurreição contra todas as formas de opressão". "Artigo 21": Todos têm o direito de resistir a qualquer ordem que ofenda os seus direitos, liberdades e garantias e de repelir pela força qualquer agressão, quando não seja possível recorrer à autoridade pública". Por seu turno, dispõe a Lei Fundamental da República Federal da Alemanha em seu artigo 20: "1. A República Federal da Alemanha é um Estado federal democrático e social. 2. Todo poder do Estado emana do povo. Este poder é exercido pelo povo mediante eleições e votações e por intermédio de órgãos especiais dos poderes legislativo, executivo e judiciário. 3. O poder legislativo está submetido à ordem constitucional; os poderes executivo e judiciário, à lei e ao Direito. 4. Contra qualquer um que tente eliminar esta ordem, todos os alemães têm o direito de resistência quando não for possível outro recurso". 
mas com ele não se confunde. Trata-se da tradição constitucionalista, cujos principais inspiradores no que se refere à fundamentação da desobediência civil em sede de filosofia político-jurídica são Hannah Arendt, Jürgen Habermas e Ronald Dworkin. Esses autores entendem a desobediência civil como um mecanismo jurídico-constitucional de proteção das garantias e direitos fundamentais, estando inscrita no corpo principiológico e valorativo dos Estados verdadeiramente republicanos. ${ }^{16}$

Nesse viés, Jürgen Habermas descreve a desobediência civil enquanto um conjunto de atos de transgressão simbólica não-violenta das regras do direito, os quais se autointerpretam como expressão de protesto dos atores sociais em face de decisões tidas como ilegítimas por parte dos detentores do poder. Tal definição poderia levar à falsa percepção de que, na visão de Habermas, a desobediência civil se resolveria enquanto simples medida extrajurídica de protesto, exatamente como a entende a tradição liberal. No entanto, o autor enfatiza que a desobediência civil garante a conexão entre a esfera da sociedade civil e o sistema político-jurídico, razão pela qual apresenta função intrassistêmica no que diz respeito à fundamentação e à legitimação do direito, atualizando os conteúdos normativos do Estado Democrático de Direito de modo a contrapô-los à inércia sistêmica da política institucional. ${ }^{17}$

Em linha semelhante, Ermanno Vitale aproxima a desobediência civil do que ele chama de "resistência constitucional". Esta seria uma espécie de desobediência que se concentraria sobre as normas de mudança de ordenamentos jurídicos em que sólidas maiorias parlamentares, capazes de perdurar por várias legislaturas, abusam do poder exclusivo que lhes conferem tais normas, seja obstruindo transformações constitucionais ou legais exigidas pelos cidadãos, seja efetivando mudanças que fragilizam seus direitos e garantias fundamentais. ${ }^{18}$

Não há dúvida de que a concepção de desobediência civil que se desenvolve na vertente constitucionalista é mais adequada ao marco paradigmático do Estado Democrático de Direito, dado que pressupõe uma cidadania participativa e solidária, a qual não se identifica com sujeitos que somente são chamados a escolher periodicamente seus representantes. Ao contrário, lançando mão de movimentos não-violentos, mas questionadores de decisões e normas específicas do sistema político-jurídico, os cidadãos desobedientes se inserem em um complexo processo político e jurídico de interpretação da Constituição. ${ }^{19}$

16 Hannah Arendt, "On civil disobedience", in: Crises of the republic, Hannah Arendt (New York: Harcourt Brace, 1972), 83-84.

17 Jürgen Habermas, Direito e democracia. Entre facticidade e validade, trad. de Flávio Beno Siebeneichler (Rio de Janeiro: Tempo Brasileiro, 1997), 117.

18 Vitale, Defenderse, 29.

19 José Antonio Estévez Araujo, La constitución como proceso y la desobediencia civil (Madrid: Trotta, 1994). 
Dessa maneira, superando a concepção legalista que durante décadas imperou no imaginário e nas práticas jurídicas, é possível entender a desobediência civil na vertente constitucionalista não enquanto um simples ato de protesto político sem aspectos verdadeiramente jurídicos, mas como uma prática organizada, não-violenta e legítima mediante a qual certa sociedade interpreta sua Constituição. Ao ser experimentada enquanto prática constitucional, os autores constitucionalistas afirmam que a desobediência civil pode se concretizar como um excepcional canal de comunicação e de integração da sociedade no Estado, apresentando imenso potencial para garantir a contínua refundação dos pactos sociais que possibilitam a manutenção e o desenvolvimento de uma comunidade político-jurídica democrática, solidária e ativa. ${ }^{20}$

De modo geral, como nota Estévez Araujo, a doutrina alemã entende que a desobediência civil se justifica como um mecanismo de realização de exceções normativas diante de leis ou atos administrativos porventura violados. Nesse sentido, e tendo em vista o âmbito especificamente penal, a desobediência civil representa o mesmo papel que o estado de necessidade, funcionando como uma exceção normativa a comandos gerais e abstratos cuja concretização gere, em determinada situação real, injustiças insuportáveis. ${ }^{21} \mathrm{Na}$ mesma linha de raciocínio, alguns teóricos defendem que a norma descumprida pelo desobediente pode ser declarada posteriormente ilegal ou inconstitucional, com o que o caráter antijurídico da ação desobediente seria relativizado. ${ }^{22}$ Como se vê, em ambos os casos a fundamentação da desobediência civil passa pela reverência e submissão ao direito constituído, o qual comparece como pano de fundo nessas construções.

$\mathrm{Na}$ verdade, a grande maioria dos autores que admitem a juridicidade da desobediência civil - e note-se que são poucos a fazê-lo - a entendem enquanto manifestação do poder constituído, o que traz enormes dificuldades teóricas para sua justificação e um baixo potencial emancipatório para sua prática. Com o fito de alinhavar os problemas que tal concepção limitada ou relativa da desobediência civil traz, analiso brevemente o pensamento de três autores clássicos - Hannah Arendt, Ronald Dworkin e Ralf Dreier - que dedicaram esforços para uma compreensão político-jurídica da desobediência civil dentro do marco - mas jamais para além dele - do Estado Democrático de Direito, característico da leitura constitucionalista. Parece-me valer a pena passar em revista essas teorias da desobediência civil - todas gestadas na matriz constitucionalista - de modo a identificar seus avanços em relação

20 Lucas Martín, "Desobediência", 63.

21 Thomas Laker, Ziviler Ungehorsam. Geschichte-Begriff-Rechtfertigung (BadenBaden: Nomos, 1986), 228-236.

22 Estévez Araujo, La constitución, 35. 
à concepção puramente liberal e, mais importante, indicar suas limitações diante da proposta de entendimento da desobediência civil enquanto manifestação permanente do poder constituinte.

Hannah Arendt começa por notar que a confusão existente no pensamento jurídico acerca da desobediência civil - ora entendida como fenômeno moral, ora como fenômeno jurídico - se deve à incompreensão de seu caráter necessariamente coletivo. ${ }^{23}$ Segundo a autora, são minorias organizadas, publicamente visíveis, não-violentas e que compartem uma mesma opinião - ainda que não uma mesma vontade - as verdadeiras artífices da desobediência civil. Ações de dissenso que se orientem com base na defesa da consciência moral individual - como é o caso de Thoreau - ou de um direito superior, seja secular ou transcendente - caso de Sócrates que, aliás, dizia nada ter contra as leis de Atenas, mas sim contra seus juízes - não podem ser tidas como expressões de desobediência civil. ${ }^{24}$ Isso porque, conforme argumenta Arendt, a mera consciência, ainda que seja de um "homem bom", é impolítica e subjetiva, incapaz de criar os vínculos necessários à caracterização de manifestações coletivas. Só onde há comunidade pode-se falar em política e, portanto, em desobediência civil. ${ }^{25}$

A vantagem de tal asserção é que ela afasta desde já a crítica vazia segundo a qual, se admitida a desobediência civil, todos fariam o que desejassem e não haveria mais qualquer respeito pela ordem constituída. Na realidade, a desobediência civil se justifica apenas enquanto ação coletiva de um grupo de cidadãos e somente assim pode ser praticada com algum sucesso. Aqui há que se recordar algo que, de tão óbvio, é quase sempre esquecido. A desobediência civil tem esse nome não apenas para se diferenciar da desobediência criminal, mas porque se apresenta fundamentalmente enquanto ação do cidadão, do cives que jamais existe sozinho, mas sim em uma comunidade política.

Apesar dessa correta fundamentação, Arendt regressa à matriz liberal da qual nunca consegue efetivamente escapar em seus escritos políticos. Ainda que a autora reconheça que a desobediência à lei talvez seja o mais impressionante fenômeno da década de 1960 em todo o mundo e que tal situação normalmente aponta para um horizonte revolucionário, com a progressiva erosão da legitimidade governamental, ${ }^{26}$ ela não leva sua percepção às últimas consequências. Apesar de a diferenciação entre o desobediente civil e o revolucionário não ser tão clara quanto aquela entre o desobediente civil e o criminoso, muito embora a não-violência seja um traço que pode distinguir

\footnotetext{
23 Arendt, "On civil disobedience", 55-56.

24 Arendt, "On civil disobedience", 56-57.

25 Arendt, "On civil disobedience", 60 e 64-65.

26 Arendt, "On civil disobedience", 69.
} 
os elementos da primeira díade, ${ }^{27}$ Arendt teme as potencialidades revolucionárias da desobediência civil e se ocupa com a difícil tarefa de encontrar-lhe um nicho institucional. Daí porque a terceira parte de seu ensaio seja dedicada à investigação de como a desobediência civil pode se adaptar aos direitos e às "instituições da liberdade", de modo a evitar a guerra civil e a revolução. ${ }^{28}$

Nessa perspectiva, Arendt passa a desenvolver um discurso em que a desobediência civil - entendida como uma criação legitimamente estadunidense e dificilmente exportável para o resto do mundo - possa se compatibilizar com uma visão de direito que se baseia no "espírito das leis estadunidenses", ou seja, aquelas capazes de garantir uma sociedade do consentimento fundada em contratos sociais horizontais. ${ }^{29}$ Como terei oportunidade de argumentar mais à frente, essa posição é contraditória com a própria caracterização arendtiana da desobediência civil enquanto fenômeno extralegal. Por ora é suficiente apenas chamar a atenção para a obsessão que, mesmo em uma autora coerente e séria como Arendt, leva sempre a se conceber a desobediência civil enquanto mecanismo de autocorreção do sistema, limitando seu campo a uma crítica específica e determinada a certas normas e políticas.

Em linha semelhante, Ronald Dworkin defende a ideia segundo a qual a desobediência civil é uma ação realizada frente a leis cuja validade é duvidosa, podendo, portanto, ser a base para um futuro hard case que se discuta em juízo. Dworkin inicia seu argumento aduzindo que a desobediência civil tem sido compreendida pela prática judiciária norte-americana mais como uma questão moral do que jurídica, indicando, contudo, que tal leitura é insuficiente e superficial. ${ }^{30}$ A questão que se põe, afirma Dworkin, é como um cidadão deve agir diante de uma lei que ele julga inválida, ou seja, inconstitucional. Há três respostas possíveis: ele deve cumprir a lei posta pela autoridade e tentar modifica-la pela via institucional, caso seja possível; ele deve descumprir a lei e agir da maneira como bem entende, desde que haja alguma corte que, com suas decisões, avalize sua interpretação; ele pode permanecer afirmando a invalidade da lei ainda que a mais alta corte jurisdicional tenha declarado sua constitucionalidade. ${ }^{31}$

Pois bem, após anotar que a Constituição nem sempre é o que a Suprema

27 Arendt, "On civil disobedience", 77.

28 Arendt, "On civil disobedience", 82.

29 Arendt, "On civil disobedience", 83-85.

30 Ronald Dworkin, Taking rights seriously. With a new appendix, a response to critics (Cambridge: Harvard University, 1978), 208.

31 Dworkin, Taking rights, 210-211. 
Corte diz, ${ }^{32}$ Dworkin se pergunta quais dessas respostas se adapta melhor às práticas jurídicas estadunidenses e a um sistema de direito liberal. De início, ele rechaça a primeira, dado que o cumprimento cego da lei levaria a uma perda de liberdade em longo prazo, já que a apreciação moral da validade das normas jurídicas é o principal meio de que dispõe a comunidade para transformar seu sistema de direito. ${ }^{33}$ A segunda solução também é rejeitada por Dworkin, visto que as cortes - inclusive a mais alta entre elas - podem mudar seus entendimentos a qualquer momento, não se colocando, portanto, como titulares de critérios absolutos para a avaliação de ações de desobediência civil. ${ }^{34}$ Dessa feita, Dworkin acaba por indicar o terceiro modelo como o mais adequado, frisando que a lealdade do cidadão é para com o direito e não para com a visão de outras pessoas sobre o que é o direito. ${ }^{35}$

Todavia, após essa surpreendente conclusão, Dworkin se apressa a relativizá-la, dizendo que a assunção da terceira alternativa não significa que as pessoas possam desconsiderar o que a Suprema Corte decidiu. Significa apenas que, quando uma lei é incerta e tal se sustenta com boas justificativas, aqueles que a desobedecem não podem ser punidos ou devem sê-lo de maneira mínima. ${ }^{36}$ Segundo entende o autor, a negativa de validade a certas e determinadas políticas e normas jurídicas faria parte do jogo de desenvolvimento do direito, o qual se dá mediante experimentação cidadã no contexto de práticas processuais em que argumentos contrários podem efetivamente ser debatidos e considerados. Ademais, Dworkin acrescenta que os casos de dissenso não são tantos e nem tão graves que possam ameaçar o sistema como um todo, razão pela qual se deve aceitar a diversidade de opiniões dos cidadãos acerca da constitucionalidade de certa lei questionada mediante um movimento de desobediência civil. ${ }^{37}$

Os problemas da tese de Dworkin são transparentes. Antes de tudo, percebe-se que ele está preocupado não com a fundamentação em si da ideia de desobediência civil, mas com a possibilidade de punição ou não daqueles que a praticam. Ainda que tal discussão seja importante, não diz muito acerca da real função da desobediência civil em contextos de exceção como o que vivemos. Na doutrina de Dworkin a desobediência civil permanece entendida como um mecanismo de autocorreção do sistema, pressupondo-se que este, na maior parte das vezes, funciona normalmente. Prova disso é que, para legitimar sua resposta aparentemente radical, Dworkin faz questão

32 Dworkin, Taking rights, 211.

33 Dworkin, Taking rights, 212.

34 Dworkin, Taking rights, 213.

35 Dworkin, Taking rights, 214.

36 Dworkin, Taking rights, 215.

37 Dworkin, Taking rights, 216-217. 
de frisar que os casos de dissenso não são numerosos e nem geram ameaças reais à manutenção do sistema geral do direito e da política. Trata-se de uma teoria não apenas grosseiramente empirista, mas conformista e inútil nos dias de hoje. No entanto, por mais que a concepção de desobediência civil de Dworkin seja limitada, é justo notar que ela abriu espaço para uma compreensão ativa do papel dos cidadãos na sua prática e interpretação, tarefa que não pode ser monopolizada pelos órgãos judiciários estatais, ideia que certamente representa um importante avanço para a fundamentação teórica da desobediência civil.

Adotando um paradigma similar ao de Dworkin, Ralf Dreier afirma que a justificação da desobediência civil se dá mediante uma operação de ponderação. Tendo assumido que o conflito entre direito e moral foi interiorizado pelo sistema jurídico e traduzido sob a forma de princípios constitucionais positivados, ${ }^{38}$ Dreier afirma que a desobediência civil é não um direito fundamental, correspondendo antes a um meio de se exercitar direitos fundamentais constitucionais, tal como a liberdade ou a igualdade. ${ }^{39}$ Dessa maneira, só se pode falar em ações de desobediência civil quando os atos que as integrem possam ser compreendidos enquanto concretizações dos princípios enunciados nas Constituições liberais, de modo que nem todo ato de desobediência será justificado - desde logo, ainda que justo, não o será se não puder ser reconduzido à matriz dos princípios constitucionais - e mesmo aqueles que o forem prima facie precisarão ser confirmados enquanto atos legítimos de desobediência mediante decisões do órgão estatal encarregado da interpretação última da Constituição. Ademais, conforme dito acima, ainda que se reconheça que determinada ação desobediente corresponde à realização de um princípio constitucional fundamental, tal não basta para garantir sua juridicidade, eis que tal ação deve ser ponderada diante de outros princípios porventura negados ou restringidos por ela.

A tradição constitucionalista da desobediência civil, em suas melhores versões, pretende integrar os cidadãos aos mecanismos constitucionais do Estado Democrático de Direito mediante práticas inclusivas, dialógicas e de amplo espectro, contribuindo assim para uma legitimação substancial do Estado de Direito, que não pode permanecer limitado às estruturas técnicas de representação, tidas por necessárias, mas insuficientes. Hoje mais do que nunca, aduzem os partidários da compreensão constitucionalista, é preciso que o poder público se torne receptivo e poroso diante das demandas da cidadania, especialmente tendo em vista o cenário de contínua colonização

38 Ralf Dreier, "Widerstandsrecht im Rechtsstaat", in: Recht und Staat im Sozialen Wandel. Festschrift für Hans Ulrich Scupin zum 80. Geburtstag, Hrsg. Norbert Achterberg et al. (Berlin: Duncker \& Humblot, 1983), 574-575.

39 Dreier, "Widerstandsrecht", 593. 
das estruturas públicas de decisão por parte de organismos privados econômicos, muitos deles transnacionais e comprometidos com a manutenção da exceção econômica. Aqui se instaura um paradoxo, pois o constitucionalismo não problematiza suficientemente a junção entre o Estado, o capital e o mercado, com o que as reformas que defende acabam por se revelar como algo meramente cosmético.

Por mais contraditório que o Estado de Direito possa ser, por mais que seja possível lê-lo como resultado das lutas sociais dos últimos dois séculos, o fato é que ele não pode negar sua função de dominação classista e, por isso mesmo, não pode representar qualquer papel verdadeiramente crítico em relação a si mesmo e à exceção econômica, tarefa que cabe a mecanismos extra-estatais como a desobediência civil. Ocorre que, como pretendo demonstrar, a desobediência civil só consegue assumir um papel crítico diante do estado de exceção econômico na medida em que se apresenta enquanto expressão do poder constituinte, e não como mecanismo de autocorreção do sistema de direito constituído. Contudo, antes de discutir tal tema, é necessário verificar em que medida é acertada a tese segundo a qual vivemos hoje sob um estado de exceção econômico, tópico da próxima seção deste trabalho.

\section{Estado de exceção econômico e pós-democracia}

Ainda que o debate sobre o estado de exceção (state of emergency, Ausnahmezustand, état d'exception) apresente muitas divergências, as quais vão desde a caracterização de sua natureza até à discussão de seus fundamentos e funções, entre os juristas parece haver certo consenso sobre suas características básicas. Como demonstrei em outro texto, ${ }^{40}$ no pensamento jurídico o estado de exceção evoca a provisória suspensão da ordem jurídica ou da Constituição (em sua totalidade ou de suas principais normas, como, por exemplo, as que garantem os direitos fundamentais). Assim, o estado de exceção seria instaurado diante de circunstâncias anormais, graves e imprevisíveis - catástrofes da natureza, conflitos civis violentos, atos de terrorismo, guerras etc. - capazes de ameaçar a estrutura do Estado de Direito, determinando assim a concentração de poderes, quase sempre nas mãos do Executivo, com o objetivo de normalizar a situação de crise.

As duas tradições jurídicas que mais se dedicaram ao problema da exceção foram a francesa (Hauriou, Mathiot, Nizard etc.) e a alemã (Friedrich, Jellinek, Schmitt etc.), esta compreendo a exceção enquanto um triunfo dos fatos diante do direito e aquela vendo-a como um tipo de adaptação do direi-

40 Andityas Soares de Moura Costa Matos, "Nómos pantokrátor: apocalipse, exceção, violência”, Revista Brasileira de Estudos Politicos 105 (Julho/Dezembro 2012), 277-342. 
to aos fatos. ${ }^{41}$ Nessa perspectiva, o estado de exceção foi entendido ora como fato político, ${ }^{42}$ ora como instituto jurídico com as mais variadas formas ${ }^{43} \mathrm{e}$ até mesmo enquanto limite indiscernível entre fato e direito. ${ }^{44}$

Todavia, ao revisitarmos a questão da situação de exceção em termos atuais, ela se problematiza, dado que a autoridade que hoje decide sobre a exceção já não é mais o Estado representativo do povo soberano, e sim o poder econômico privado, com o que se firma uma nova situação epocal: o estado de exceção econômico. Segundo vários autores, haveria hoje uma espécie de estado de exceção permanente nas democracias ocidentais, o que poderia ser comprovado pelos seguintes fatos tornados cotidianos: conflitos bélicos de baixa intensidade (mas contínuos), a guerra contra o terrorismo, o desmonte das estruturas do Welfare State, o ressurgimento de violências étnicas, tribais, religiosas e nacionais, a formação de uma nova plutocracia e a dominação das instâncias políticas de decisão pelos mercados especulativos. ${ }^{45} \mathrm{Na}$ realidade, por se fundar em razões de emergência e crise econômica estrutural, tal situação é melhor descrita como um estado de exceção econômico permanente, ${ }^{46}$ já que a normalidade das ordens jurídicas - tanto as nacionais como a internacional - encontra-se indefinidamente suspensa pelo poder econômico. Com efeito, as principais decisões políticas - inclusive aquelas que dizem respeito às guerras e às violências globais - passam hoje pela necessária mediação do capital. ${ }^{47}$

41 François Sainte-Bonnet, L'état d'exception (Paris: Presses Universitaires de France, 2001), 14.

42 Carl Schmitt, Political theology. Four chapters on the concept of sovereignty, trad. de George Schwab (Chicago: University of Chicago, 2005), 14-15; Raymond Carré de Malberg, Contribution à la théorie générale de l'état. Tome I (Paris: Centre Nationale de la Recherche Sociale, 1962), 610-623; Olivier Beaud, "Le souverain”, Pouvoirs 67 (1993), 44.

43 Robert Hoerni, L'état de nécessité en droit public fédéral suisse. Étude juridique sur les pleins pouvoir (Genève: s./ed., 1917), 202; Léon Duguit, Traité de droit constitutionnel (Paris: De Boccard, 1923), 162; Maurice Hauriou, Précis de droit constitutionnel. 2. ed (Paris: Sirey, 1929), 425; André Mathiot, "La théorie des circonstances exceptionnelles", in: Mélanges Mestre (Paris: Sirey, 1956), 416-424 e Frede Castberg, "Le droit de nécessité en droit constitutionnel”, in: Mélanges Gidel (Paris: Sirey, 1961), 116-117.

44 Giorgio Agamben, Homo sacer. O poder soberano e a vida nua, trad. de Henrique Burigo (Belo Horizonte: Universidade Federal de Minas Gerais, 2010), 25.

45 Qiao Liang e Wang Xiangsui, Unlimited warfare, (West Palm Beach: News-Max, 2002); Alain Joxe, The empire of chaos, (New York: Semiotexte, 2002); Carlo Galli, La guerra globale, (Bari: Laterza, 2002) e Agamben, Homo sacer.

46 William E. Scheuerman, "The economic state of emergency", Cardozo Law Review 5-6 (2000), vol.21, 1869-1894 e Giovanni Messina, "Stato economico d'eccezione e teoria della governance: ovvero la fine della politica", Revista Brasileira de Estudos Políticos 107 (Julho/Dezembro 2013), 99-148.

47 Agamben, Homo sacer, 26-37. 
O termo estado de exceção econômico foi cunhado nos anos 20 e 30 do século passado para indicar as drásticas mudanças impostas na economia e na produção/distribuição de bens pelos esforços de guerra, denotando a especificidade da situação em confronto com aquilo tido por "normal". Todavia, hoje a expressão se refere a algo completamente diverso. Não se trata mais das transformações temporárias que a guerra, enquanto acontecimento político internacional, impõe às economias nacionais, mas sim das mudanças que o poder econômico global capitalista exige do Estado e da sociedade, ainda que ausente um contexto de guerra declarada.

Antonio Valdecantos afirma que a "exceção dos mercadores" se caracteriza fundamentalmente pela inexistência de uma autoridade soberana, visto que tal centralização é repudiada pelo mercado, o qual exige fluxo, rapidez e horizontalidade incompatíveis com o antigo paradigma moderno da soberania. De fato, qualquer autoridade suprema é um entrave ao livre jogo do mercado, que só funciona na medida em que se lhe permite auto-reproduzir-se com intensidade sempre crescente. A exceção econômica se caracterizaria assim por uma competição irrestrita - com o que vem à luz seu caráter propriamente bélico - que tem como consequência a economização total da vida, de modo que toda conduta humana possa ser lida como conduta de mercado, tendo a economia, por fim, se transformado em uma vivência total. ${ }^{48}$

Há uma extensa literatura que discute a crise do Estado-Nação e o surgimento de poderes econômicos globais que parecem exercer uma soberania imperial sobre o planeta, de natureza acêntrica, fluida e sob a forma de rede, ${ }^{49}$ conformando a emergência de um novo tipo de autoridade privada que, sem se confundir com o poder soberano, se traduz sob as formas móveis da governance. Esta, sob o pretexto de atingir níveis de maior eficiência, competitividade e produtividade no cenário econômico capitalista, muitas vezes desconsidera e limita as conquistas das lutas sociais traduzidas em termos de direitos e garantias fundamentais, as quais são compreendidas pelo capital como meros obstáculos ao desenvolvimento econômico a serem afastados. ${ }^{50}$

48 Antonio Valdecantos, La excepción permanente o la construcción totalitaria del tiempo (Madrid: Díaz \& Ponz, 2014), 63-68.

49 Giovanni Arrighi, The long twentieth century (London: Verso, 1994); Pietro Barcelonna, Il declino dello stato. Riflessioni di fine secolo sulla crisi del progetto moderno (Bari: Dedalo, 1998); Michael Hardt e Antonio Negri, Empire (Cambridge: Harvard University, 2000); Robert Brenner, The boom and the bubble (London: Verso, 2002); Paul Q. Hirst, From statism to pluralism. Democracy, civil society and global politics (London/Bristol: Routledge, 2003); David Harvey, A brief history of neoliberalism (Oxford: Oxford University, 2005).

50 Robert Keohane e Joseph Nye, "Introduction", in: Governance in a globalizing world, eds. Joseph S. Nye e John D. Donahue (Washington: Brookings Institution, 2000); Saskia Sassen, "The state and globalization", in: The emergence of private authority 
Tal fenômeno - que pode ser lido como uma espécie de gestão privada de interesses públicos - erode e fragiliza as estruturas clássicas de controle e de proteção dos direitos, típicas dos Estados Democráticos de Direito, dando origem ao que Sheldon S. Wollin chamou ironicamente de "democracias S.A.", ou seja, governos formalmente democráticos que, na prática, se submetem às determinações privadas oriundas da esfera econômica. Esse fenômeno gera uma espécie de totalitarismo invertido graças ao qual as grandes corporações transnacionais subvertem os princípios democráticos, transformando seres vivos e recursos naturais em commodities a serem exploradas. Ao mesmo tempo, as "democracias S.A." - cujos maiores (mas não únicos) exemplos seriam os EUA e a União Europeia - se omitem frente ao esvaziamento das liberdades públicas e dos direitos sociais duramente obtidos ao longo das lutas dos últimos 250 anos. Dessa maneira, ao invés de participar das decisões político-econômicas que afetam suas vidas, os cidadãos das "democracias S.A." são submergidos em um excesso de consumismo e de espetacularização da vida social que os impede de opor qualquer alternativa verdadeiramente política ao monopólio da decisão por parte das instâncias econômicas globalizadas. ${ }^{51}$

Mesmo autores que, a exemplo de Danilo Zolo, são resistentes a reconhecer o fim do projeto do Estado de Direito, precisam, no entanto, admitir que tal projeto se encontra em grave crise, já que as estruturas tradicionais de garantia de direitos e de controle do poder político - v.g., representação, tripartição do poder, soberania, processos eleitorais etc. - foram capturadas pelo poder econômico. Tal se deveria, em grande parte, ao caráter mais lento e rígido do subsistema jurídico diante da flexibilidade e da rapidez evolutiva de subsistemas como o científico-tecnológico e o econômico, que possuem intensa capacidade de autoprogramação e autocorreção, gerando uma crise da função reguladora do direito. ${ }^{52}$

A tese de Zolo é, contudo, tímida, dado que se centra na crise da capacidade regulatória do direito sem se perguntar quais são os elementos de fundo que a determinam. Segundo me parece, estamos vivendo uma verdadeira mudança paradigmática que afeta não só a função de regulação do direito,

in global governance, eds. Rodney Hall e Thomas Biersteker (Cambridge: Cambridge University Press, 2002); Jan Kooiman, Governing as governance (London: Sage, 2003); Anne-Mette Kjaer, Governance (Cambridge: Polity, 2006); Maria Rosaria Ferrarese, La governance tra politica e diritto (Bologna: Il Mulino, 2010) e Messina, "Stato".

51 Sheldon S. Wolin, Democracy incorporated. Managed democracy and the specter of inverted totalitarianism (Princeton: Princeton University Press, 2010).

52 Danilo Zolo, "Teoria e crítica do estado de direito", in: O estado de direito. História, teoria, crítica, orgs. Pietro Costa e Danilo Zolo (São Paulo: Martins Fontes, 2006), $72-73$. 
mas as próprias bases democráticas em que, ao menos retoricamente, ele se sustenta. Essa mudança se relaciona à passagem de um momento em que a democracia vigorava enquanto projeto social compartilhado para uma era assumidamente pós-democrática. Com essa expressão se indica a manutenção formal dos procedimentos e normas da democracia ao mesmo tempo em que a política e o governo voltam a ser monopolizados por grupos privilegiados, tal como ocorria na época pré-democrática. ${ }^{53}$ É surpreendente notar que até mesmo um autor como Habermas, tão pouco crítico diante do modelo ideal regulador do Estado Democrático de Direito e suas fragilidades em termos de democracia real, tenha usado o termo "pós-democracia". Habermas lançou mão dele para indicar uma das possíveis configurações da política europeia, em artigo que tem como pano de fundo as medidas antidemocráticas tomadas por Nicolas Sarkozy e Angela Merkel durante o encontro dos G-20 em 2011. Tais medidas objetivavam impedir a execução de um referendum proposto na Grécia pelo então Primeiro Ministro, Yorgos Papandréu. ${ }^{54}$

Segundo Rancière, a pós-democracia envolve o paradoxo da eliminação consensual da democracia por meio de práticas tidas por democráticas, mas que, ao contrário, apenas concretizam a aliança entre mercado e Estado, fazendo idênticas a política e a gestão do capital. ${ }^{55}$ Nesse ponto, há que se ter em vista a reflexão de Maurizio Lazzarato, para quem seria errôneo analisar a crise econômico-financeira que "justifica" a pós-democracia excepcional em termos de um "antes" e um "depois", como se, uma vez superada a crise, os Estados pudessem voltar à sua condição liberal, abandonando as medidas autoritárias, privatistas e centralizadoras que hoje os caracterizam. Na verdade, continua Lazzarato, a crise não impôs qualquer mudança na natureza do liberalismo, servindo apenas para revelar uma verdade histórica, qual seja: o capitalismo nunca foi liberal, tendo sempre se apresentado enquanto capitalismo de Estado. Nesse sentido:

Hoy en día, el Estado, en su versión no-mínima, interviene no una vez, sino dos, para cumplir sus funciones: la primera, para salvar las finanzas y también a los bancos y a los liberales; la segunda, para imponer a las poblaciones el pago de los costes políticos y económicos de lo anterior. La primera vez, a favor de los mercados; la segunda, en contra de la sociedad. ${ }^{56}$

53 Colin Crouch, Post-democracy (London: Polity, 2004).

54 Jürgen Habermas, "Europe's post-democratic era", The Guardian (10 de novembro de 2011), acedido em 09 de outubro de 2015, http://www.theguardian.com/commentisfree/2011/nov/10/jurgen-habermas-europe-post-democratic.

55 Jacques Rancière, La mésentente (Paris: Galilée, 1995) e Jacques Rancière, Aux bords du politique (Paris: La Fabrique, 1998).

56 Maurizio Lazzarato, "Capitalismo de estado y soberania: la gubernamentalidad en la crisis actual”, in: Posdemocracia, guerra monetaria y resistencia social en la Europa de hoy, Badiou et al. (Madrid: Errata Naturae, 2015), 35. 
Em um contexto mais geral, Antonio Negri entende que a principal característica da pós-modernidade é a radical modificação da dimensão jurídico-administrativa em relação à organização econômica capitalista, de sorte que o capital efetivamente subsumiu toda a sociedade. Em suas palavras:

La sociedad ha sido completamente absorbida en la organización económica $y$ en el poder de mando del capital: esto es, se ha "realizado" la "subsunción" de la sociedad en el capital, cuyas figuras son esencialmente las del capital financiero, que domina y reorganiza la división del trabajo en el plano global, construye la ganancia sobre el trabajo material e inmaterial de la "fábrica social" y extrae renta de la producción-reproducción de la vida y de la comunicación-circulación de los valores. El dinero es su poder constituyente, la forma en que domina el "común productivo", se apropia de él y lo hace funcional a la explotación y a su jerarquización..$^{57}$

Ao se perguntar como pôde ser possível um trânsito tão radical - da democracia à pós-democracia característica do estado de exceção econômico - sem qualquer resistência significativa, Yannis Stavrakakis afirma que o crédito e a dívida foram os instrumentos capazes de, ao substituir o Welfare State, constituir uma população de consumidores integrados à tessitura social unicamente pela via econômica do consumo, de modo que a gradual perda e limitação de direitos sociais e políticos foi obscurecida pela constante oferta de crédito a populações que hoje se veem escravizadas pelo capital. ${ }^{58}$

Pois bem, é nesse contexto de exceção econômica pós-democrática que se põe o problema da realização e da garantia de direitos fundamentais em Estados que se querem democráticos, o que, evidentemente, envolve graves dificuldades, eis que as reivindicações sociais da cidadania tendem a ser desconsideradas ou mesmo negadas sob o pano de fundo de situações de emergência que têm como pressuposto exatamente a impossibilidade de diálogos profundos entre o poder público e a sociedade, assumindo-se acriticamente a naturalização da crise capitalista, vista enquanto horizonte limitador de quaisquer expectativas de liberação ou mesmo de emancipação social. Nessa perspectiva surge a importância da retomada da desobediência civil, vista não simplesmente como estratégia de pressão política, mas enquanto mecanismo político-jurídico constituinte de novas possibilidades de vivência social opostas ao monólogo que o capital mantém consigo mesmo.

57 Antonio Negri, "Prefacio a la nueva edición en español", in: El poder constituyente. Ensayo sobre las alternativas de la modernidad, Antonio Negri, trad. de Simona Frabotta y Raúl Sánchez Cedillo, ed. Montserrat Galcerán Huguet y Carlos Prieto del Campo (Madrid: Traficantes de Sueños/Secretaría de Educación Superior, Ciencia, Tecnología e Innovación, 2015), 13.

58 Yannis Stavrakakis, "La sociedad de la deuda. Grecia y el futuro de la posdemocracia", in: Posdemocracia, guerra monetaria y resistencia social en la Europa de hoy, Badiou et al. (Madrid: Errata Naturae, 2015), 11. 


\section{Poder constituído/constituinte/desinstituinte e potência destituinte}

\subsection{Poder constituinte originário e poder constituinte derivado}

Desde Platão o pensamento ocidental se estrutura com base em dualismos que possibilitam uma leitura simplificada e mística do mundo, apresentando-o como um cenário no qual lutam o bem e o mal. Todavia, mais do que reduzir a complexidade do real ao apresentá-lo sob a forma estanque de duas forças opostas, os dualismos servem ao propósito fundamental de toda filosofia conservadora, seja antiga ou contemporânea: negar o fluxo e o movimento, a mudança, a contingência e a impermanência.

Quando se determina a existência de duas realidades constantemente enfrentadas e opostas - corpo e alma, estrutura e superestrutura etc. - se dificulta ou mesmo se impossibilita o trânsito entre ambas, as quais se põem então como substratos imodificáveis, de modo que, por exemplo, corpo e alma, ainda que estejam no mesmo ser, se diferenciam radicalmente. No pensamento dual, nenhum dos dois polos pode se converter totalmente no outro. Ademais, como é óbvio, o dualismo exige a produção de uma hierarquia entre os contrários, de maneira que um deles controle o seu oposto e o sobredetermine. Com isso, a riqueza da realidade, na qual as coisas são e não são ao mesmo tempo - intuía Heráclito em seu fragmento $10^{59}$ - se perde em esquemas abstratos que, por terem sido introjetados no pensar desde sua infância, parecem corresponder ponto a ponto à "verdade".

Talvez nenhuma outra disciplina como o Direito tenha realizado com tanta perfeição os ditames da filosofia dualista. A partir de seus começos, o pensamento jurídico sô pode se orientar teórica e praticamente com base em estruturas duais, tais como direito natural e direito positivo, pessoa e coisa, direito material e direito processual, direito público e direito privado e muitas outras. No início do século XX, Hans Kelsen criticou os dualismos jurídicos, vendo neles expressões de uma consciência conservadora e autoritária. ${ }^{60}$ Ademais, Kelsen indicou que o mais insuspeito desses dualismos - aquele que separa direito e Estado - não é mais do que um expediente político para, reconhecendo a oposição entre ambas as instâncias, submeter o direito objetivo aos desejos juridicamente injustificáveis dos detentores do poder político, que passam então a traduzir suas vontades subjetivas sob o léxico do "interesse público", do "fato do príncipe", da "soberania" e, mais recentemente, do "estado de exceção", com o único objetivo de retirar suas

59 Cf. Hermann Dielz e Walther Kranz (orgs.), Die Fragmente der Vorsokratiker. 6. ed (Berlin: Weidmannsche, 1951).

60 Hans Kelsen, "Gott und Staat", Logos: Internationale Zeitschrift für Philosophie der Kultur (XI) 3 (1922-1923), 261-284. 
ações do campo de controle das normas jurídicas. Contra essa tendência Kelsen lançou a tese da unidade entre direito e Estado, de sorte que este só pode ser compreendido enquanto ordem jurídica centralizada, ou seja, expressão antropomórfica dos processos de interpretação e criação do direito. Por isso mesmo, conclui Kelsen, o Estado se encontra totalmente regido por normas jurídicas, de modo que nenhum de seus atos pode se pretender imune diante das regulações do direito. ${ }^{61}$

Para além das polêmicas que até hoje a tese kelseniana gera, o que pretendo reter de sua lição iconoclasta é a ideia segundo a qual os dualismos no direito têm, assim como na filosofia, uma função ideológica clara, qual seja, impedir a compreensão da contingência e da transformação, alinhando-se a uma interpretação conservadora das dinâmicas sociais que pretendem normatizar. Nessa perspectiva, o dualismo que agora pretendo criticar é aquele que separa o poder constituído e o poder constituinte, de modo a discutir as implicações teóricas e práticas que surgem a partir da localização da desobediência civil nesses dois campos.

O dualismo poder constituinte/poder constituído só faz sentido quando se pensa o exercício do poder político em contextos não democráticos e de cunho transcendente, tais como os que hoje se justificam com base na figura inegavelmente religiosa da representação, esse dispositivo que, no dizer de Carl Schmitt, faz visível algo invisível, presentifica o ausente. ${ }^{62}$ Uma teoria do direito radicalmente democrática - e isso quer sobretudo dizer: que recusa a representação - concebe apenas um poder continuamente constituinte, dado que o titular desse poder não se divide, não se representa, não se especializa: são as pessoas mesmas em suas vidas quotidianas que, ao produzirem a sociedade, se põem como titulares absolutas do poder constituinte. Ao contrário, quando se pensa - como nos nossos dias é não apenas normal, mas quase obrigatório para que um discurso sobre a política seja levado a sério formas despotencializadas de democracia - quer dizer, formas "seguras" de democracia - se cria uma fratura fundamental no sujeito democrático, que passa a não poder realizar ações e decisões reais, sendo a partir daí convertido em "representado".

Uma divisão central no próprio corpo do poder entre ato e potência, entre constituído e constituinte, somente se justifica quando se considera, de maneira totalmente arbitrária, que o titular desse poder também está cindido. De fato, o povo se apresenta em duas versões já tradicionais no pensamento político ocidental: como sujeito e como objeto do poder político, demos e plethos, populus e plebs, popolo grasso e popolo minuto, Povo com maiúscula e povo com minúscula.

61 Kelsen, "Gott", 261-284.

62 Carl Schmitt, Teoría de la constitución, trad. de Francisco Ayala (Madrid: Alianza, 1982), 209. 
Na primeira configuração, a do Povo-sujeito, este é rapidamente substituído por seus representantes, os quais se encarregam de resguardar o poder constituído. Esquece-se, como ironiza Benjamin, que os Parlamentos devem suas existências às revoluções efetivadas com base no poder constituinte e chega-se ao absurdo de sustentar que o Povo não é, na verdade, um sujeito prévio à sua representação unificante, que teria então caráter constitutivo. É como se a existência física, produtiva e conflituosa de mulheres e homens só ganhasse densidade política e significabilidade institucional na medida em que se deixa invisibilizar e unificar pelas artes mágicas da representação.

Por seu turno, o povo-objeto corresponde ao resto dessa operação constitucional em que o Povo-sujeito acaba englobado e substituído por representantes. O povo-objeto comparece como o âmbito de ação do poder constituído, correspondendo à dimensão em que esse poder age. Ao mesmo tempo, o povo-objeto aparece enquanto titular de um abstrato poder constituinte potencial, que pode ser ativado apenas em situações emergenciais ou de extrema gravidade. Assim se produz o paradoxo segundo o qual, no pensamento jurídico tradicional, o poder constituído sobredetermina o evanescente poder constituinte.

Com o objetivo de garantir ainda mais fortemente a imobilização e o esvaziamento do poder constituinte, um novo dualismo é gravado em seu corpo, como se não fosse suficiente subordiná-lo ao poder constituído confiado aos representantes do Povo-sujeito que, de fato, não existe. Trata-se da distinção entre poder constituinte originário e poder constituinte derivado, compreendendo-se na primeira expressão a possibilidade de fundação de uma nova ordem constitucional ex nihilo e, na segunda, o poder - confiado apenas aos representantes do Povo - de intervir nessa nova ordem constitucional para revisá-la pontualmente.

Não são necessários grandes esforços intelectuais para compreender que a ideia de poder constituinte derivado corresponde a mais um controle - um desacelerador ou amortecedor, na linguagem do último Schmitt ${ }^{63}$ - imposto à sempre incômoda potência que envolve o poder constituinte. De fato, se a nova ordem pode ser constantemente remodelada e melhorada pelo poder constituinte derivado, se esvazia drasticamente a função do poder constituinte originário enquanto dimensão efetivamente produtora de normatividade contrafática. $\mathrm{O}$ poder constituinte passa então a sobreviver apenas na dimensão retórica, tendo por função ideológica indicar que um dia o Povo-sujeito teve o poder em suas mãos e, na impossibilidade de exercê-lo, o confiou a seus representantes, os quais agora podem inclusive fazer aos poucos o que

63 Carl Schmitt, Staat, Großraum, Nomos. Arbeiten aus den Jahren 1916-1969, Hrsg. mit einem Vorwort und mit Anmerkungen versehen von Günter Maschke (Berlin: Duncker \& Humblot, 1995). 
os revolucionários fizeram de um só golpe: modificar a ordem constitucional e adaptá-la a seus desejos. Em uma configuração institucional como essa, qualquer expressão do poder constituinte enquanto tal é não apenas desnecessária, mas perigosa, pois atentaria contra os processos e procedimentos de autocorreção que a nova ordem criou para si mesma.

Percebe-se que a operação que separa o poder constituinte em originário e derivado anula o próprio poder constituinte, na medida em que o objetivo deste - mudar a ordem político-constitucional - é assumido pelo poder constituinte derivado e exercido em doses homeopáticas, determinando que toda transformação da ordem seja regrada, pontual, segura e controlada de modo intrassistêmico. Não há dúvida acerca do caráter conservador de tal construção, pois desconsidera o fato de que as reformas e as revisões possibilitadas pelo poder constituinte derivado são efetivadas pelos representantes do Povo-sujeito, e não pelo povo-objeto, que é o único efetivamente existente. Ademais, a ideia de poder constituinte derivado desconsidera a necessidade de quebra total da ordem atual e de seus princípios que, por definição, não podem sofrer reforma ou revisão. Ora, quando a ordem constituída se estrutura com base nas determinações do mercado e do capital, quando o horizonte do estado de exceção econômico permanente se impõe de maneira indiscutível diante dos procedimentos e dos tecnicismos pelos quais se pretende reformar essa mesma ordem, se percebe quão antidemocrático é o dispositivo que separa o poder constituinte em originário e derivado, correspondendo a uma tentativa de sequestro do poder democrático verdadeiramente popular.

Uma filosofia do direito democrática precisa negar resolutamente a distinção entre poder constituinte originário e poder constituinte derivado, assumindo a existência unicamente do poder constituinte, sem adjetivos e em constante produção. Para tanto, há que se compreender que o poder constituinte não se traduz enquanto marco temporal que comparece no sistema, como ocorre hoje, apenas enquanto signo de uma origem pretensamente popular. Ao contrário, o poder constituinte deve ser entendido enquanto processo contínuo, constantemente produtor de normas, subjetividades e conflitos que encontram suas soluções sempre precárias no próprio movimento de sua afirmação. Caso se aceite a premissa de que a democracia radical - e não a representativa - corresponde à única verdadeira democracia, por ser a única que não exige títulos prévios (econômicos, de gênero, raciais, intelectuais etc.) para o exercício autonômico do poder político, é necessário aceitar igualmente que o poder constituinte é singular, indivisível e permanentemente operante. Mais ainda: em uma democracia radical o poder constituinte ocupa o lugar reservado à soberania no sistema nômico do poder constituído traduzido sob formas liberais-capitalistas.

Como bem afirma Antonio Negri, toda ciência jurídica pretende domar e controlar o poder constituinte. As estratégias para tanto são muitas e vão des- 
de a invenção do dualismo já criticado (poder constituinte originário e derivado) até à identificação completamente sem sentido entre poder constituinte e representação, apontando sempre para a submissão do poder constituinte ao poder constituído, o que, para além de ilógico, mal esconde a verdadeira intenção desse proceder, que é exatamente negar o caráter absoluto, indeterminado e potencial do poder constituinte. Nesse sentido, a teoria jurídica contemporânea em geral e o constitucionalismo em especial devem responder por suas tentativas sempre renovadas de diminuir e submeter o poder constituinte, vendo nele uma marca do excesso democrático a ser contido. ${ }^{64}$

O constitucionalismo não é lido por Negri como um movimento democrático, tratando-se antes de uma tentativa de submeter o poder político a certos limites ditados pelo sistema do liberalismo. Deve-se atentar e frisar sempre que, independentemente da lavagem cerebral que os professores de Direito Constitucional pretendem realizar em seus alunos, liberalismo e democracia não são termos sinônimos. Se bem entendidos, correspondem mesmo a ideias contrárias e irreconciliáveis. Nesse contexto, o choque com o poder constituinte é inevitável. Por ser uma expressão radical da vontade democrática, o poder constituinte se opõe à representação e ao sistema de check and balances, apontando para o futuro, nunca para o passado, diferentemente do que ocorre com o constitucionalismo liberal. Segundo Negri:

O paradigma constitucionalista é sempre o da "constituição mista", da mediação da desigualdade na desigualdade, portanto um paradigma não democrático. O paradigma do poder constituinte, ao contrário, é aquele de uma força que irrompe, quebra, interrompe, desfaz todo equilíbrio preexistente e toda continuidade possível. [...] No conceito de poder constituinte está a ideia de que o passado não explica mais o presente, e que somente o futuro pode fazê-lo. [...] O constitucionalismo é uma doutrina jurídica que conhece somente o passado, é uma referência contínua ao tempo transcorrido, às potências consolidadas e à sua inércia, ao espírito que se dobra sobre si mesmo - ao passo que o poder constituinte, ao contrário, é sempre tempo forte e futuro. ${ }^{65}$

Ainda que o tema do poder constituinte seja hoje tratado por autores que, tais como Negri, se alinham a uma concepção libertária e democrática como a que ora exponho, é curioso lembrar que devemos uma das mais radicais reflexões sobre o tema a Carl Schmitt, jurista de perfil reconhecidamente autoritário. Em sua obra mais extensa e que condensa todo seu pensamento constitucional, Schmitt, na contramão do constitucionalismo liberal-

64 Antonio Negri, O poder constituinte. Ensaio sobre as alternativas da modernidade, trad. de Adriano Pilatti, 2. ed (Rio de Janeiro: Lamparina, 2015), 1-13.

65 Negri, $O$ poder, 11-12. 
-burguês, afirma que o poder constituinte é inconstituível e permanente. ${ }^{66}$ Isso quer dizer que o poder constituinte não pode ser limitado por formas e procedimentos predeterminados, pois tal significaria constitucionalizar o poder constituinte, o que seria absurdo. Impor limites ao poder constituinte implicaria a assunção da ideia de que existe alguma instância que lhe seja superior, pressuposição completamente carente de sentido em um Estado verdadeiramente democrático no qual a fonte da normatividade é a vontade do povo e não dimensões metafísicas ou de qualquer modo externas à conflitividade factual do mundo social.

Além disso, Schmitt entende que o poder constituinte do povo permanece ativo mesmo após a entrada em vigor de uma nova Constituição, o que traz como consequência a possibilidade sempre presente de questionamento radical do sistema político constituído. Entre as situações de fato que exigem a decisão do poder constituinte e o apelo ao povo, Schmitt cita o caso das lacunas constitucionais - hipótese teórica interessante, mas que não diz respeito ao objeto do presente trabalho - e o dos conflitos constitucionais que afetam as bases da decisão política em que se funda a Constituição. ${ }^{67}$ Para Schmitt, mais do que um conjunto de normas, a Constituição encarna uma vontade coletiva traduzida em decisão política. Caso essa decisão seja desconsiderada pelos representantes do povo, cabe a este retomar a posição originariamente constituinte.

Não se discute que tal construção serviu a Schmitt como fundamento para uma proposta político-jurídica plebiscitária e de corte profundamente autoritário. Meu objetivo aqui não é, obviamente, transplantar o pensamento schmittiano à realidade atual, mesmo porque tal autor não comunga de maneira alguma com o pressuposto que perpassa todo este trabalho, o qual se filia à ideia de democracia radical. $\mathrm{O}$ que pretendo reter da lição schmittiana é a incomensurabilidade do poder constituinte, não o uso equívoco de tal potência para quaisquer fins, sejam eles democráticos ou autocráticos. Reconheço que desenvolvo um discurso ontológico que se arrisca em todo momento a ser mal interpretado, pois, de fato, a mera afirmação da potência constituinte do povo ou da multidão, como quer Negri, não traz consigo qualquer garantia democrática. Como bem ilustra o pensamento de Schmitt, o poder constituinte se mostra inicialmente sob a forma da potência, não envolvendo conteúdos factuais necessários. Por ser incomensuravelmente aberta, tal potência não está determinada por nada, nem mesmo pela ideia de democracia radical. Retomo e problematizo esse tema a seguir, sendo importante para tanto evidenciar o caráter ilimitado e mesmo abismal do poder constituinte.

66 Schmitt, Teoría, 97-99.

67 Schmitt, Teoría, 94-95. 


\subsection{Destituição e desinstituição}

Diante dos riscos inerentes ao poder constituinte, põe-se a necessidade de pensá-lo em termos concretos tendo em vista os reais contextos sociais em que ele pode vir a ser exercido. É aqui que o apelo à noção de poder desinstituinte surge não como uma garantia de que o poder constituinte se constituirá democraticamente - tal garantia é impossível -, mas sim que ele operará tendo em vista a negação do atual sistema apropriante patrocinado pelo capital, com o que há boas chances para a construção de sociedades democráticas. Aqui, uma vez mais, há que se aceitar que toda ação política envolve uma aposta que, contudo, não precisa ser cega. A constituição de novas estruturas político-jurídicas pelo poder constituinte popular, partindo necessariamente da desconstituição das antigas formas capitalistas, indica a assunção de uma nova visão de mundo por parte dos reais titulares do poder político. O gesto mesmo da negação do que está aí - os dispositivos hierárquicos e apropriantes constituídos com base no capital - equivale a uma criação pela via inversa, no sentido de um futuro aberto em que nada está garantido, a não ser a impossibilidade de se continuar vivendo sob um sistema político-jurídico-econômico global que, já se tendo mostrado claramente insano, ameaça a própria existência física do planeta em que se desenvolve. Em outras palavras: não podemos saber o que surgirá a partir da potência constituinte, que é imensurável e relativamente indeterminada, mas podemos sim afirmar, com base no poder desinstituinte, que esse novo mundo não será nada semelhante ao atual sistema excepcional do capital.

Pode-se compreender o poder desinstituinte enquanto fuga ou êxodo das formas institucionais pelas quais se expressa o poder político-econômico contemporâneo, traduzido em instituições como o Estado, os bancos e os mercados globais. Ainda que todo ato constituinte envolva necessariamente dinâmicas desinstituintes, a natureza radical da crítica que pretendo imprimir à totalidade do sistema político-jurídico atual exige que a desinstituição seja pensada de maneira própria, tendo em vista que não se trata de um simples momento lógico necessário para futuras constituições.

Neste ponto, é necessário esclarecer que a ideia que ora desenvolvo de poder desinstituinte não se confunde com a noção de potência destituinte de Giorgio Agamben, ainda que ambas as concepções guardem certas semelhanças. E isso por uma razão muito simples, mas de fundamental importância: Agamben concebe a potência destituinte como pura inoperosidade. Por inoperosidade não se entende inércia, mas uma atividade que desativa os mecanismos do direito e da política marcados pela violência exceptiva que os institui, abrindo-lhes novas possibilidades de uso. Contudo, a destituição em Agamben é concebida como uma realidade que em nenhum momento se relaciona à instituição, ou seja, com o paradigma da produção. Inoperosidade 
significa então o não operar, quer dizer, o deixar de constituir obras, como se todo poder constituinte envolvesse em si mesmo o pecado original da violência e da cisão entre uma dimensão ordenada - árquica - e outra desordenada - anárquica. É com base nessa leitura que Agamben constitui os dualismos potestas e auctoritas, vida e direito, vida nua e vida politicamente qualificada, homem e animal, reino e glória, entre muitos outros que povoam sua obra. ${ }^{6}{ }^{\mathrm{Em}}$ todas essas díades aparece uma estrutura exceptiva que, atuando incessantemente entre ambas, as torna indiscerníveis, cindido a experiência factícia por meio de um movimento de exclusão inclusiva pelo qual certa dimensão - os direitos fundamentais, por exemplo - só se torna pensável ou politicamente relevante na medida em que é incluída diferencialmente no sistema pelo ex-capere (o "capturar fora") próprio da exceção. No exemplo dado tal se traduz pela percepção de que só se garantem direitos mediante gestos legitimadores da violência institucional do Estado que os afirma.

Segundo Agamben, conceber - como a tradição ocidental vem fazendo desde a revolução francesa - um poder constituinte capaz de transformar a realidade político-jurídica não significa mais do que trocar de amos e senhores, já que um poder que tenha sido abatido por uma violência constituinte fatalmente ressurgirá sob outras formas. É que, em tal hipótese, não se desativou a dialética da violência que põe (poder constituinte) e mantém (poder constituído) o direito. Assim, para Agamben, poder constituinte e poder constituído formam um sistema, de maneira que o constituído se funda no constituinte e o constituinte - inicialmente visto como poder que se dá fora do Estado e continua existindo mesmo após o ato de constitucionalização acaba sendo capturado pelo instituído, passando a sobreviver apenas enquanto poder de revisão da Constituição, tal como resta claro na clássica definição de Sieyès. ${ }^{69}$ Para evitar tal redundância paradoxal, a receita de Agamben passa pelo abandono da díade poder constituinte/constituído e pela assunção da radical inoperosidade da potência destituinte, que não produz obra - não violenta, portanto -, mas apenas desativa obras já existentes, preparando-as para um novo uso mediante aquilo que Walter Benjamin chama de destituição (Entsetzung). ${ }^{70} \mathrm{O}$ autor italiano conclui:

Secondo lo schema che abbiamo tante volte descritto, costituente è quella figura del potere in cui una potenza destituente viene catturata e neutralizzata, in modo de assicurare che essa non possa rivolgersi contro il potere o l'ordine giuridico come tale, ma solo contro una sua determinata figura storica. ${ }^{71}$

\footnotetext{
68 Agamben, L'uso, 334-336.

69 Agamben, L'uso, 336-337.

70 Agamben, L'uso, 339-341.

71 Agamben, L'uso, 338.
} 
Ao que me parece, os equívocos na construção de Agamben são evidentes. Antes de mais, a ligação umbilical que ele vê entre poder constituinte e poder constituído é um dado histórico, não ontológico. Pode-se muito bem pensar e realizar um poder constituinte que, tal como seu nome indica, não seja subsumível ou limitável pelo poder constituído. Foi exatamente o que tentei teorizar linhas atrás ao negar a distinção entre poder constituinte originário e poder constituinte derivado, a qual, de fato, funciona como um dispositivo de captura do poder constituinte por parte do poder constituído. Caso se conceba um poder constituinte permanente que não se relacione hierarquicamente com o poder constituído, que até mesmo se lhe oponha no sentido de que, sendo permanente, jamais dará lugar a instituições fixas que possam se legitimar sob a etiqueta do "poder constituído", não há razão para afirmar, como faz Agamben, que toda instituição manterá viva a violência originária da arqué que põe e conserva o direito. Para tanto é preciso, conforme já indiquei, conceber um poder desinstituinte capaz de desativar as instituições do capital, do Estado e do mercado. Tal poder, diferentemente da potência destituinte de Agamben, se relaciona diretamente ao poder constituinte: não como se representasse um seu momento lógico, mas enquanto estrutura necessária para se abater o poder constituído e substituí-lo por um poder constituinte contínuo e permanente.

Se em Agamben a dialética entre poder constituinte e poder constituído tem que ser totalmente abandonada para se negar a relação entre ambos, o que é possibilitado pela potência destituinte, em minha proposta se trata de quebrar o vínculo histórico e retórico entre poder constituído e poder constituinte, liberando este do sequestro patrocinado por aquele. Para realizar tal projeto é necessária uma força desinstituidora que avance contra aspectos institucionais e concretos do capitalismo e do Estado, abrindo espaço para a produção de novas subjetividades, novos usos e novas juridicidades que nascerão a partir do poder constituinte permanente, o qual não deve ser visto sempre e desde já, como quer Agamben, enquanto mera expressão da violência do nómos. Ao contrário, o poder constituinte, como figura originalmente rebelde, envolve uma excedência produtiva que não pode ser contida pelos mecanismos institucionais do poder constituído. ${ }^{72}$

O desejo de liberdade se traduz não na dialética entre poder constituinte e poder constituído, mas na relação horizontal entre poder desinstituinte e poder constituinte permanente. Friso mais uma vez: se o processo histórico de afirmação do direito ocidental se fundou na violência apropriadora e hierarquizante, algo que é incontestável, não há qualquer razão para se afirmar que sempre será assim e que toda produtividade traz em si o signo dessa arqué. Afirmar tal tese, a da indissolubilidade entre violência, produção e constitui-

72 Negri, "Prefacio", 19-20. 
ção, significa confundir história e ontologia e assim bloquear as possibilidades concretas de transformação social. Nem tudo que foi tem que continuar a ser, já que a história é obra humana e não uma forma que se impõe em sua mesmidade ao longo do percurso dos homens e suas sociedades. E entre as ontologias, como bem sabe Agamben, há sempre aquelas da possibilidade, da abertura, da potência-do-não. Nelas se fundam as lutas sempre produtivas da multidão por uma realidade an-árquica, ou seja, não-separadora, não-apropriante, não-hierarquizante.

Diferentemente do poder constituinte, que sob o paradigma moderno correspondia à ideia de soberania, traduzindo-se como potência imprevisível capaz de criar novas formas que não podem ser conhecidas de antemão, o poder desinstituinte se apresenta enquanto conteúdo negativo, ou seja, possibilidade que se atualiza à medida que nega as estruturas determinadas e concretas que integram os dispositivos institucionais de fato existentes. Com efeito, ainda que não saibamos como será um mundo pós-capitalista, pensá-lo exige necessariamente que abramos mão do projeto histórico de tomar as estruturas do Estado, envolvendo antes um ato de deserção em relação aos poderes que pretendem nos fazer crer que vivemos em "democracias respeitáveis". ${ }^{73}$

Como notou Furio Jesi de maneira certeira em seu já lendário estudo sobre a simbologia e a mitologização da revolta, uma das mais temíveis conquistas do capitalismo foi ter tornado suas estruturas verdadeiros padrões e símbolos de força, de modo que todas as organizações que o criticam e tentam vencer, tais como os partidos e sindicatos de esquerda, sentem-se inexoravelmente impelidos a reproduzir suas formas, como se essas estivessem fora da história e representassem símbolos não-contingentes de poder. ${ }^{74} \mathrm{En}$ tretanto, a exemplo de toda mitologização não-genuína, aquela do poder capitalista corresponde a mero acidente epocal, não envolvendo nenhum conteúdo de verdade extra-histórica. Nesse contexto, o poder desinstituinte se mostra como uma força que, mais do que abrir espaço ao novo, torna possível a historicização do capitalismo e, consequentemente, sua crítica radical e derrocada. Para cumprir esse papel o poder desinstituinte precisa ser pensado em sua radicalidade ontológica própria, e não como mero símile negativo do poder constituinte, em especial quando este é entendido enquanto afirmação soberana do povo ou do Estado, tal como fazem os constitucionalistas em geral. Trata-se de criar um novo léxico político em que o lugar da palavra e da experiência soberanas - principalmente a do mitologema "povo soberano"

73 Anselm Jappe, “¿Todos contra la banca?”, in: Posdemocracia, guerra monetaria y resistencia social en la Europa de hoy, Badiou et al. (Madrid: Errata Naturae, 2015), 121.

74 Furio Jesi, Spartakus. Simbología de la revuelta, trad. de María Teresa D’Meza, ed. Andrea Cavalletti (Buenos Aires: Adriana Hidalgo, 2014), 87-88. 
- seja desativado e tornado impróprio, inautêntico, inútil para quaisquer fins que não sejam os da dominação e cisão social que se combate sob a bandeira de um poder constituinte que nada tem a ver com aquele assim nomeado pela tradição do constitucionalismo.

Esse ponto é importante e não deve ser menosprezado. Parece-me efetivamente perigoso conceber o poder constituinte de modo formal e vazio segundo o paradigma constitucionalista moderno da soberania, o qual tem em Schmitt seu último grande teórico. Por ser aberto e indeterminado, o poder constituinte poderia originar qualquer tipo de sociedade. Isso demonstraria que o poder constituinte não é uma panaceia para todos os males, visto que sua ação inclusive poderia levar os homens a se organizarem sob formas ainda mais autoritárias que aquelas impostas pelo capital. Tal consequência seria inevitável e constituiria propriamente o caráter político do poder constituinte. De fato, o político se identifica não com a definição e a caracterização do inimigo, mas com a tentativa de ordenar a contingência e a indeterminação próprias das estruturas sociais. Dessa maneira, agir politicamente significaria apostar. Esse seria o verdadeiro sentido trágico do poder constituinte.

Contudo, como dito antes, não se trata aqui de uma aposta cega. Se o poder constituinte efetivamente funciona com base na indeterminação e na abertura que podem dar origem a quaisquer configurações sociais, algumas inclusive piores que o capitalismo, é necessário garantir um grau mínimo de segurança. Ninguém aposta se não tiver certa confiança mais ou menos intensa em resultados positivos. Segundo minha proposta, essa confiabilidade se garante ao poder constituinte quando ele é pensado - e praticado - em relação ao poder desinstituinte. Este, diferentemente do poder constituinte, não é aberto nem indeterminado, mas sim configurado pela realidade que nega. O poder desinstituinte se define por meio das instituições existentes, apresentando sempre conteúdo negativo. Aquilo que o poder desinstituinte desinstitui é o mínimo a partir do qual agirá o poder constituinte, que pode de fato constituir tudo, menos aquilo que foi negado pelo poder desinstituinte, caso esteja em jogo um projeto político coerente. Em uma linha de pensamento similar, Negri afirma que o poder constituinte não deve ser hoje pensado como potência vazia. Por não existir na pós-modernidade um "dentro" e um "fora", toda força política se põe em estreita relação com a historicidade presente. Assim, o poder constituinte sempre terá seu sentido determinado pelas resistências e singularidades contra as quais se choca, com o que, diferentemente do que adverte Agamben, não poderá jamais se traduzir sob a forma da exceção. ${ }^{75}$

Instituições como o Estado, o banco, a bolsa de valores, a propriedade privada, a herança e o contrato, na medida em que tenham sido desinstituí-

75 Negri, "Prefacio", 19. 
das, não poderão ser reconfiguradas pelo poder constituinte, que encontrará na ordem negada pelo poder desinstituinte um limite à sua infinita maleabilidade. Desse modo, torna-se possível que se aposte não sem riscos - o que seria um contrassenso -, mas sim assumindo seriamente que se pretende construir sociedade mais dignas, diferentes daquelas que foram desinstituídas. $\mathrm{O}$ poder desinstituinte funciona como uma garantia de não regresso ao capitalismo, abrindo um imenso campo de experiências em que, apesar de nada estar assegurado, se excluem de início algumas alternativas que já se revelaram na história como inaceitáveis a partir de um ponto de vista ético - não há justificativa para a submissão de $99 \%$ da humanidade ao $1 \%$ de indivíduos e empresas que dominam o poder político-econômico - e ineficientes a partir de um ponto de vista produtivo - a multidão produz o comum mais e melhor do que o capital, hoje limitado a uma alucinada valorização do valor, inclusive sob perversas formas financeiras, rentistas e virtuais.

É nessa complexa dinâmica entre a deserção desinstituinte em relação ao sistema político-jurídico atual da exceção econômica permanente e a configuração constituinte de um direito que vem radicalmente democrático que compreendo o papel da desobediência civil, tal como discutido na próxima e última seção deste trabalho.

\section{Desobediência civil e poder desinstituinte/constituinte}

José Antonio Estévez Araujo conceitua a desobediência civil como uma atuação ilegal, pública, não-violenta e efetivada com o objetivo de transformar certa lei ou política governamental. ${ }^{76}$ Por essa definição, parece que a desobediência civil pode ser praticada apenas dentro dos marcos de um sistema jurídico dado, ao qual, de maneira geral, se respeita, objetivando-se apenas modificar alguns de seus aspectos específicos. Essa é, como visto, a compreensão da desobediência civil que vários autores desenvolvem ao tratar tal tema no contexto do poder constituído.

Nada obstante, mesmo alguns teóricos que entendem a desobediência civil enquanto expressão do poder constituído, reconhecem que ela pode se voltar, em situações extremas, à crítica e à tentativa de substituição da totalidade de um sistema político-jurídico, como ficou evidente nas ações dos desobedientes capitaneadas por Gandhi, as quais se iniciaram tendo em vista algumas políticas discriminatórias do governo inglês e logo se transformaram numa campanha contra o sistema colonial a que a India estava sujeita. ${ }^{77}$

76 Estévez Araujo, La constitución, 22.

77 Arendt, "On civil disobedience”, 77 e Estévez Araujo, La constitución, 28-29. 
Essa situação demonstra que a desobediência civil, mais do que um mecanismo de autocorreção do direito constituído, pode funcionar como expressão de um poder constituinte multitudinário, com o que excede o direito positivo dado, apresentando-se enquanto fonte de juridicidade e não seu resultado ou produto. Para que a desobediência civil cumpra esse papel, é preciso que circunstâncias específicas estejam presentes e possam ser adequadamente fundamentadas em certa ideia de direito que, sob o ponto de vista assumido neste texto, apresenta natureza democrático-radical. A hipótese até aqui desenvolvida é que hoje essas circunstâncias são plenamente existentes sob a forma do estado de exceção econômico permanente. Mais do que colonizar, a exceção econômica transmudou os Estados Democráticos de Direito. Ao que me parece, foi atingido o ponto de não-retorno, graças ao qual assistimos à rápida desconstituição dos direitos e garantias liberais que, apesar de nunca terem funcionado em sua plenitude - de resto, como tudo que é projeto humano -, cumpriram um importante papel histórico ao inserir parcialmente no debate e na vivência política camadas e grupos sociais antes explorados e oprimidos.

É importante sublinhar que a desobediência civil não é a única e talvez nem a mais importante estrutura de manifestação do poder constituinte. Há diversas outras formas, tanto passivas - a greve geral revolucionária, por exemplo - quanto ativas - insurgência, resistência armada, revolução etc. - que têm por objetivo a transformação total do quadro político-jurídico-econômico da exceção. Muitas dessas modalidades de poder constituinte lançam mão de métodos violentos que, nem por isso, são em si mesmos ilegítimos. Não se pode esquecer as lições de Schmitt e Benjamin sobre a co-naturalidade entre direito e violência. Com efeito, a normatividade que conhecemos surgiu de atos originários de tomada da terra, ${ }^{78}$ os quais passaram a ser justificados miticamente com o emprego de metáforas moralizantes, ao passo que o sistema jurídico monopolizou para si o uso da violência, tida como meio absoluto do direito e, portanto, não compartilhável com outras esferas sociais. ${ }^{79}$ Nada obstante, também não se pode olvidar o caráter histórico e não ontológico das teses de Schmitt e Benjamin, já que dizem respeito a certa experiência do direito - a ocidental, surgida na Grécia, e que hoje se apresenta enquanto direito capitalista-apropriador - e não a toda experiência jurídica possível.

78 Carl Schmitt, Der Nomos der Erde im Völkerrecht des Jus Publicum Europæum (Berlin: Duncker \& Humblot, 1974).

79 Walter Benjamin, "Zur Kritik der Gewalt", in: Gesammelte Schriften, Walter Benjamin, Band II.1, Herausgegeben von R. Tiedemann e H. Schweppenhäuser (Suhrkamp: Frankfurt-am-Main, 1999), 179-204. 
Poder e normatividade - e não violência e hierarquia - são os elementos de qualquer experiência jurídica. Se hoje essas díades são totalmente confundidas, tal se deve à imediata e irrefletida identificação entre o que é - o direito capitalista - e o que pode ser - outras formas de direito. Se levarmos a sério o convite que Agamben faz à "geração que vem" para pensar um direito em que a violência esteja desativada, sobressai, entre as diversas formas constituintes desse novo direito, a desobediência civil, exatamente por seu caráter não-violento que, numa linguagem mística, não acumula karma ou, para ser mais claro, não mantém ativo o mecanismo do direito capitalista que exige sempre mais violência para se fundamentar e se realizar. A partir dessa perspectiva, a desobediência civil pode ser pensada enquanto instituição jurídica radicalmente argumentativa, muito mais do que qualquer teoria da argumentação ligada aos poderes constituídos - violentos por natureza - pode admitir.

Estévez Araujo sistematiza as concepções de desobediência civil discutidas na primeira seção deste artigo afirmando que se pode entendê-la ora como teste de constitucionalidade, quando mediante o ato de desobediência se questiona diretamente a validade constitucional de determinada lei, ora como exercício direto de um direito já reconhecido na Constituição, quando, por exemplo, a autoridade nega o direito à manifestação e ao protesto e os desobedientes desconsideram tal proibição. No primeiro caso, trata-se de uma postura mais ativa, que se dirige ao Poder Legislativo, enquanto na segunda hipótese os desobedientes adotam posturas mais passivas e se voltam contra medidas e decisões do Poder Judiciário ou Executivo. O que importa, contudo, é que em ambas as situações os desobedientes questionam atos de ponderação de valores e princípios efetivados pelo poder público - seja ao criar ou aplicar leis -, tentando demonstrar que certas opiniões, circunstâncias e pontos de vista não foram adequadamente considerados e sopesados. ${ }^{80}$ Percebe-se que essas compreensões da desobediência civil se ligam à necessidade de comover ou ativar a opinião pública, objetivando modificar decisões dos três ramos clássicos do poder soberano. Contudo, a natureza profundamente antidemocrática de tal poder permanece inquestionada em sua essência.

Em um quadro em que qualquer transformação político-jurídica relevante passa pela necessária mediação dos poderes do mercado e do Estado-capital, a desinstituição patrocinada pela desobediência civil é fundamental para a constante reafirmação da perenidade do poder constituinte, comparecendo como uma importante - mas não única, como já dito - via de luta para a constituição de direitos que vêm verdadeiramente democráticos e não calcados no nómos proprietário e violento que hoje marca - de maneira explícita ou implícita - as experiências pós-modernas de normatividade.

80 Estévez Araujo, La constitución, 144-145. 
É evidente a ineficácia das concepções que limitam a função da desobediência civil a cenários institucionais de normalidade, quando então ela funciona como válvula de escape ou, no melhor dos casos, como mecanismo de autocorreção ou mesmo de auto-integração do direito. Nessas hipóteses, a ação desobediente é constrangida a assumir a validade de toda a estrutura político-jurídica vigente, questionando-lhe aspectos específicos sem, contudo, se dirigir a uma desinstituição geral do sistema. Todavia, como argumentado na segunda seção deste texto, a situação em que os Estados Democráticos de Direito estão hoje imersos só pode ser entendida sob o viés da exceção econômica permanente, quando a união entre Estado, finanças e mercado vem à tona e determina de facto a direção antipopular das políticas estatais, a ilimitação do poder privado capitalista e o esvaziamento das conquistas históricas dos movimentos de luta por direitos iniciados no século XVIII e radicalizados por grupos operários, negros, feministas e outros durante os séculos XIX e XX.

Nesse contexto, entender a desobediência civil enquanto dispositivo de ajuste ou correção do poder constituído significa negar-lhe toda potência efetivamente transformadora e democrática, vendo-a como mais um dos muitos mecanismos técnicos que, controlados e referendados pelo Estado-mercado - refiro-me, por exemplo, a Ações Declaratórias de Inconstitucionalidade, Ações de Descumprimento de Preceito Fundamental, Mandados de Injunção etc. -, só podem representar um papel retórico, indicando e comprovando a suposta normalidade de um sistema de direito que, na verdade, já está há muito esgotado. De fato, esse sistema é agora imune a qualquer reforma verdadeira que ponha em jogo os fundamentos privatistas, egoístas e individualistas em que se funda. Parece-me impróprio e contraditório derivar a fundamentação da desobediência civil a partir dos princípios de um sistema nômico-proprietário que em seu desenvolvimento histórico tem sido separador, hierárquico e violento, características que se opõem aos traços definidores da desobediência civil, que é pública, horizontal e pacífica.

Hoje se tornou urgente pensar uma política contestatória e crítica que não se proponha a ser apenas uma violência diferente daquela monopolizada pelo nómos proprietário. Essa é a única maneira de escapar ao assujeitamento total gerado pelo capitalismo tardio, quando a subjetivação contempladora garantida pela sociedade do espetáculo se justifica e se mantém conjuntamente com a violência legalizada e institucionalizada característica do estado de exceção. No mundo imperial da exceção econômica permanente, a produção e a ação têm que ser totais, ininterruptas e irreflexivas. Por isso cada resistência violenta imposta ao sistema o fortalece, já que o leva a ativar novos mecanismos de controle e subjetivação.

Na verdade, o estado de exceção só pode sobreviver e prosperar caso seja constantemente justificado pela resistência que o questiona e, assim, de modo 
paradoxal, o exige e mantém. Diferentemente do que pensava Foucault, a resistência não é a outra face do poder, mas o poder mesmo. Resistir ao estado de exceção, ainda que justificadamente e com bons argumentos, é então uma maneira de ativar os arcanos do poder, que descansam na ação produtora e reprodutora de um mundo social cindido. Nessa perspectiva, "contra la excepción permanente no cabe rebelión, porque el no cesar de rebelarse constituye el primero de todos los mandatos que tal excepción impone". ${ }^{81}$ Isso é claramente perceptível nas lutas multitudinárias que ocorreram entre 2011 a 2013, quando a explosão de indignação popular foi primeiramente tida por legítima para logo em seguida servir como justificativa para um aprofundamento sem precedentes - ao menos nos Estados autointitulados "democráticos" - da exceção, com a aprovação de várias leis e medidas administrativas que criminalizam a contestação pública da ordem capitalista, chegando-se mesmo ao absurdo de vulnerar os princípios basilares da presunção de inocência e do devido processo legal, bem como o direito à informação, à intimidade e à manifestação, como ocorreu na Espanha graças à famigerada Ley Mordaza.

No Brasil o processo se fez particularmente claro. Tendo sido surpreendido por junho de 2013, quando uma série de movimentos acêntricos, horizontais e espontâneos tomaram as ruas das principais cidades brasileiras e dificultaram o espetáculo da Copa das Confederações e o aumento das tarifas do transporte público, o poder excepcional pôde apresentar tais movimentos como símbolos da barbárie e da desordem, arquitetando posteriormente uma estrutura de contenção, intimidação e controle raras vezes experimentada no país, graças à qual a Copa do Mundo ocorreu sem maiores incidentes em 2014. De modo simétrico, a aparente vitória consistente no recuo do Estado e de seus parceiros econômicos no que diz respeito ao aumento das tarifas do transporte público foi rapidamente revertida em 2015, e dessa vez sem que o espetáculo midiático se incomodasse com a extrema violência policial mediante a qual os protestos em São Paulo, Rio de Janeiro e Belo Horizonte foram tratados e, em pouquíssimos dias, desacreditados e integrados à narrativa triunfal que a ordem faz de si mesma. Na vida política como na Física, toda ação gera reação, ainda que no palco das lutas humanas a reação não se dê na mesma direção e esteja longe de ter intensidade proporcional. Daí a necessidade de se valorizar as potencialidades desinstituintes e constituintes de uma inação como aquela proposta pela desobediência civil.

$\mathrm{Na}$ interpretação assumida neste texto, em que o poder constituinte está estreitamente relacionado ao poder desinstituinte, a desobediência civil, desde que considerada para além da tradicional interpretação liberal e reformista, parece ser um dos mais adequados mecanismos para se pensar e agir

81 Valdecantos, La excepción, 156. 
desinstitucionalmente, e isso com uma imprescindível vantagem estratégica: sendo desprovida de violência, a desobediência civil não se liga diretamente às formas de ação do Estado-capital, geneticamente marcadas que são pela necessidade de monopolização da violência.

A exigência de não-violência é absolutamente central para o sucesso das ações desobedientes opostas ao poder constituído, dado que muitas vezes as práticas violentas de movimentos sociais que possuem causas justas são utilizadas como razões para as respostas sempre mais impiedosas do Estado. A estratégia da não-violência tem por objetivo não apenas despertar o sentido moral do adversário - como queria Gandhi -, mas também influir na opinião pública, de maneira a dirigi-la contra o Estado e em favor dos desobedientes que pretendem a instituição de novas estruturas político-jurídicas. ${ }^{82}$ A tal percepção estratégico-argumentativa se soma o aspecto institucional segundo o qual o uso da violência por organizações de resistência é terminantemente proibido nas democracias constitucionais. ${ }^{83} \mathrm{Com}$ a estratégia da não-violência se facilita a legitimação da ideia de desobediência civil no contexto do poder constituído que ela pretende criticar e superar.

\section{Conclusão}

Conforme expõe Costas Douzinas, o ato de desobediência torna possível desvincular as ações, a conduta e o comportamento das pessoas da matriz econômica capitalista centrada no consumo, na dívida e no julgamento moral imposto às camadas populares, convocadas para suportar indefinidamente os efeitos nocivos da crise econômica permanente em que vivemos. Ao questionar o suposto continuum entre lei e justiça, a desobediência deixa de ser um ato individual de feição moralizante e se apresenta enquanto prática social de caráter coletivo e emancipador, podendo constituir novas subjetividades ao retirar os sujeitos do circuito desejo-consumo-frustração. ${ }^{84}$

$\mathrm{O}$ ato ontológico do desobediente não precisa estar organizado por nenhum partido político, sindicato, ideologia ou qualquer outra estrutura centralizadora, tratando-se antes de um movimento que, partindo da resistência, luta pelo direito a ter direitos, tratando-se, portanto, do grau zero da política

82 Estévez Araujo, La constitución, 26.

83 Theodor Ebert, "Die Auswirkungen von Aktionen zivilen Ungehorsams in parlamentarischen Demokratien: eine vergleichende Betrachtung", in: Widerstand im Rechtsstaat. 10. Kolloquium der Schweizerischen Akademieder Geisteswissenschaften, Hrsg. Peter Saladin und Beat Sitter (Freiburg: Universitätsverlag, 1988), 93.

84 Costa Douzinas, "Crisis, resistencia e insurrección: el despertar de la izquierda radical en Grecia”, in: Posdemocracia, guerra monetaria y resistencia social en la Europa de hoy, Badiou et al. (Madrid: Errata Naturae, 2015), 175-176. 
graças ao qual novas subjetividades são constituídas. ${ }^{85} \mathrm{O}$ que importa aqui é criar formas emancipadas de ler a realidade social e estar no mundo, desconstituindo as subjetividades proprietárias e hierárquicas na medida em que se desconstituem as instituições que as reproduzem no cotidiano. Para realizar essa tarefa, a desobediência civil tem um papel central. Ela precisa se encarnar não apenas nas ideias abstratas aqui discutidas, mas em ações muito concretas: abandono do trabalho, greve geral nos serviços públicos, não pagamento de impostos e taxas, ocupação permanente e pacífica das sedes do poder constituído, abstenção eleitoral maciça, fuga do sistema bancário, multiplicação do cooperativismo etc.

Em contradição com sua tese final - já comentada na primeira seção -, Hannah Arendt indica que a desobediência civil, como fenômeno extralegal, pode efetivamente se mostrar enquanto potência revolucionária. Após notar que todas as sociedades humanas mudam, estão em constante fluxo e que, não obstante, por isso mesmo precisam de alguma estabilidade, Arendt afirma que o direito pode estabilizar e normatizar as mudanças depois que elas ocorrem, mas as mudanças mesmas sempre resultam da ação de potências extralegais, ${ }^{86}$ ou seja, de algo que excede o direito, tal como ocorre com o poder constituinte. Daí porque a autora chegue - ao que parece, a contragosto - a uma conclusão muito similar àquela que desenvolvo neste trabalho, segundo a qual a desobediência civil corresponde a uma das respostas possíveis à crise das instituições político-jurídicas. Algumas das palavras finais de Arendt merecem ser citadas, em especial devido ao efeito deslocador que produzem se comparadas à visão liberal e despotencializada de desobediência civil que ela tenta salvaguardar ao entendê-la enquanto forma de autocorreção do sistema político-jurídico constituído:

Perhaps an emergency was needed before we could find a home for civil disobedience, not only in our political language, but in our political system as well. An emergency is certainly at hand when the established institutions of a country fail to function properly and its authority loses its power, and it is such an emergency in the United States today that has changed voluntary association into civil disobedience and transformed dissent into resistance. It is common knowledge that this condition of latent or overt emergency prevails at present - and, indeed, has prevailed for some time - in large parts of the world; what is new is that this country is no longer an exception. ${ }^{87}$

A tese que desenvolvi neste artigo demonstra que as palavras de Arendt possuem a sombria pervivência do profético. Se podiam ser aplicadas com certas reservas ao momento histórico em que ela vivia, quando os mecanis-

85 Costa Douzinas, Philosophy and resistance in the crisis (London: Polity, 2013).

86 Arendt, "On civil disobedience", 82.

87 Arendt, "On civil disobedience", 101-102. 
mos do Estado de Direito começavam a se desvanecer nos EUA graças ao agigantamento do Poder Executivo, da instauração de uma guerra imoral e injurídica no Vietnã e do controle - ainda incipiente - da dimensão política pela economia, parecem, contudo, muito mais adequadas aos nossos dias, quando o estado de exceção econômico tornou-se a regra e a emergência cotidiana instaurada pelo capitalismo de desastre só pode ser superada, mais do que por um novo nómos da terra (conforme previsto por Schmitt), pela desativação que apenas a recusa radical do desobediente pode constituir.

\section{Referências}

Agamben, Giorgio. Homo sacer. O poder soberano e a vida nua, trad. de Henrique Burigo. Belo Horizonte: Universidade Federal de Minas Gerais, 2010.

Agamben, Giorgio. L'uso dei corpi. Vicenza: Neri Pozza, 2015.

Arendt, Hannah, "On civil disobedience", in: Crises of the republic, Hannah Arendt. New York: Harcourt Brace, 1972, 49-102.

Arrighi, Giovanni. The long twentieth century. London: Verso, 1994.

Barcelonna, Pietro. Il declino dello stato. Riflessioni di fine secolo sulla crisi del progetto moderno. Bari: Dedalo, 1998.

Beaud, Olivier. "Le souverain", Pouvoirs, nº 67 (1993).

Benjamin, Walter, "Zur Kritik der Gewalt", in: Gesammelte Schriften, Walter Benjamin, Band II.1, Herausgegeben von R. Tiedemann e H. Schweppenhäuser. Suhrkamp: Frankfurt-am-Main, 1999, 179-204.

Biondo, Francesco. Tra diritto e morale. Saggio sulla disobbedienza civile. Torino: Giappichelli, 2008.

Brenner, Robert. The boom and the bubble. London: Verso, 2002.

Carré de Malberg, Raymond. Contribution à la théorie générale de l'état. Tome I. Paris: Centre Nationale de la Recherche Sociale, 1962.

Castberg, Frede, "Le droit de nécessité en droit constitutionnel", in: Mélanges Gidel. Paris: Sirey, 1961.

Castellar, João Carlos. (org.), Manifestações de junho de 2013. Avanços e retrocessos um ano depois. Rio de Janeiro: POD, 2015.

Cosi, Giovanni. Saggio sulla disobbedienza civile. Storia e critica del dissenso in democrazia. Milano: Giuffrè, 1984.

Crouch, Colin. Post-democracy. London: Polity, 2004.

Deutschland. Grundgesetz für die Bundesrepublik Deutschland, 1949, acedido 19 de julho de 2011, http://www.brasil.diplo.de/contentblob/2677068/Daten/750845/ ConstituicaoAlemao_PDF.pdf.

Dielz, Hermann e Kranz, Walther. (orgs.), Die Fragmente der Vorsokratiker. 6. ed. Berlin: Weidmannsche, 1951.

Douzinas, Costa, "Crisis, resistencia e insurrección: el despertar de la izquierda radical en Grecia", in: Posdemocracia, guerra monetaria y resistencia social en la Europa de hoy, Badiou et al. Madrid: Errata Naturae, 2015, 163-185.

Douzinas, Costa. Philosophy and resistance in the crisis. London: Polity, 2013. 
Dreier, Ralf, "Widerstandsrecht im Rechtsstaat", in: Recht und Staat im Sozialen Wandel. Festschrift für Hans Ulrich Scupin zum 80. Geburtstag, Hrsg. Norbert Achterberg et al. Berlin: Duncker \& Humblot, 1983, 573-593.

Duguit, Léon. Traité de droit constitutionnel. Paris: De Boccard, 1923.

Dworkin, Ronald. Taking rights seriously. With a new appendix, a response to critics. Cambridge: Harvard University, 1978.

Ebert, Theodor, "Die Auswirkungen von Aktionen zivilen Ungehorsams in parlamentarischen Demokratien: eine vergleichende Betrachtung", in: Widerstand im Rechtsstaat. 10. Kolloquium der Schweizerischen Akademieder Geisteswissenschaften, Hrsg. Peter Saladin und Beat Sitter. Freiburg: Universitätsverlag, 1988, 73-116.

Estévez Araujo, José Antonio. La constitución como proceso y la desobediencia civil. Madrid: Trotta, 1994.

Ferrarese, Maria Rosaria. La governance tra politica e diritto. Bologna: Il Mulino, 2010.

Figueiredo, Rubens. (org.), Junho de 2013. A sociedade enfrenta o Estado. Perdizes: Summus, 2014.

Galli, Carlo. La guerra globale. Bari: Laterza, 2002.

Gandhi, Mohandas Karamchand e Duncan, Ronald Frederick Henry. Selected writings of Mahatma Gandhi. London: Faber and Faber, 1951.

Gandhi, Mohandas Karamchand. "Duty of disobeying laws", Indian Opinion, (7 and 14 September 1907).

Gandhi, Mohandas Karamchand. "For passive resisters", Indian Opinion, (26 October 1907).

Gohn, Maria da Glória. Manifestações de junho de 2013 no Brasil e praças dos indignados no mundo. Petrópolis: Vozes, 2014.

Habermas, Jürgen. Direito e democracia. Entre facticidade e validade, trad. de Flávio Beno Siebeneichler. Rio de Janeiro: Tempo Brasileiro, 1997.

Habermas, Jürgen. "Europe's post-democratic era", The Guardian, (10 novembro 2011), acedido 09 de outubro de 2015, http://www.theguardian.com/commentisfree/2011/nov/10/jurgen-habermas-europe-post-democratic.

Hardt, Michael e Negri, Antonio. Empire: Cambridge: Harvard University, 2000.

Harvey, David. A brief history of neoliberalism. Oxford: Oxford University, 2005. Hauriou, Maurice. Précis de droit constitutionnel. 2. ed. Paris: Sirey, 1929.

Hirst, Paul Q. From statism to pluralism. Democracy, civil society and global politics. London/Bristol: Routledge, 2003.

Hoerni, Robert. L'état de nécessité en droit public fédéral suisse. Étude juridique sur les pleins pouvoir. Genève: s./ed., 1917.

Jappe, Anselm, “'Todos contra la banca?”, in: Posdemocracia, guerra monetaria y resistencia social en la Europa de hoy, Badiou et al. Madrid: Errata Naturae, 2015, 115-126.

Jesi, Furio. Spartakus. Simbología de la revuelta, trad. de María Teresa D’Meza, ed. Andrea Cavalletti. Buenos Aires: Adriana Hidalgo, 2014.

Joxe, Alain. The empire of chaos. New York: Semiotexte, 2002.

Judensnaider, Elena et al. Vinte centavos. A luta contra o aumento. São Paulo: Veneta, 2013. 
Keohane, Robert e Nye, Joseph, "Introduction", in: Governance in a globalizing world, eds. Joseph S. Nye e Donahue, John D. Washington: Brookings Institution, 2000.

Kelsen, Hans. "Gott und Staat", Logos: Internationale Zeitschrift für Philosophie der Kultur, (XI) 3 (1922-1923), 261-284.

King Jr., Martin Luther. A testament of hope. The essential writings and speeches of Martin Luther King Jr, edited by James Melvin Washington. New York: Harpercollins, 1991.

King Jr., Martin Luther. Por qué no podemos esperar, trad. de J. Romero Maura. Barcelona: Ayma, 1973.

Kjaer, Anne-Mette. Governance. Cambridge: Polity, 2006.

Kooiman, Jan. Governing as governance. London: Sage, 2003.

Laker, Thomas. Ziviler Ungehorsam. Geschichte-Begriff-Rechtfertigung. Baden-Baden: Nomos, 1986.

Lazzarato, Maurizio, "Capitalismo de estado y soberania: la gubernamentalidad en la crisis actual", in: Posdemocracia, guerra monetaria y resistencia social en la Europa de hoy, Badiou et al. Madrid: Errata Naturae, 2015, 29-42.

Liang, Qiao e Xiangsui, Wang. Unlimited warfare. West Palm Beach: News-Max, 2002.

Lucas Martín, Francisco Javier de. "Desobediência e democracia: a hora da cidadania", Revista da Faculdade de Direito da Universidade Federal de Goiás, n 1 (Janeiro/Junho 2013), vol. 37, 58-72.

Mathiot, André, "La théorie des circonstances exceptionnelles", in: Mélanges Mestre. Paris: Sirey, 1956.

Matos, Andityas Soares de Moura Costa. "A desobediência civil como direito fundamental”, Revista Del Rey Jurídica, n 16 (2006), ano 8.

Matos, Andityas Soares de Moura Costa. Filosofia radical e utopias da inapropriabilidade. Uma aposta an-árquica na multidão. Belo Horizonte: Fino Traço, 2015.

Matos, Andityas Soares de Moura Costa. "Nómos pantokrátor: apocalipse, exceção, violência", Revista Brasileira de Estudos Políticos, n 105 (Julho/Dezembro 2012), 277-342.

Messina, Giovanni. "Stato economico d'eccezione e teoria della governance: ovvero la fine della politica", Revista Brasileira de Estudos Políticos, n 107 (Julho/ Dezembro 2013), 99-148.

Moore Jr., Barrington. Injustiça. As bases sociais da obediência e da revolta. São Paulo: Brasiliense, 1987.

Negri, Antonio. O poder constituinte. Ensaio sobre as alternativas da modernidade, trad. de Adriano Pilatti. 2. ed. Rio de Janeiro: Lamparina, 2015.

Negri, Antonio, "Prefacio a la nueva edición en español", in: El poder constituyente. Ensayo sobre las alternativas de la modernidad, Antonio Negri, trad. de Simona Frabotta y Raúl Sánchez Cedillo, ed. Montserrat Galcerán Huguet y Carlos Prieto del Campo. Madrid: Traficantes de Sueños/Secretaría de Educación Superior, Ciencia, Tecnología e Innovación, 2015, 11-21.

Nizard, Lucien. Les circonstances exceptionnelles dans la jurisprudence administrative, Paris: Librairie Générale de Droit et Jurisprudence, 1962. 
Portugal. Constituição da república portuguesa, 1976, acedido em 19 de julho de 2011, http://www.parlamento.pt/Legislacao/Paginas/ConstituicaoRepublicaPortuguesa.aspx.

Rancière, Jacques. Aux bords du politique. Paris: La Fabrique, 1998

Rancière, Jacques. La mésentente. Paris: Galilée, 1995.

Sainte-Bonnet, François. L'état d'exception. Paris: Presses Universitaires de France, 2001.

Sassen, Saskia, "The state and globalization", in: The emergence of private authority in global governance, eds. Rodney Hall e Thomas Biersteker. Cambridge: Cambridge University Press, 2002.

Scheuerman, William E. "The economic state of emergency", Cardozo Law Review, n 5-6 (2000), vol. 21, 1869-1894.

Schmitt, Carl. Der Nomos der Erde im Völkerrecht des Jus Publicum Europæum. Berlin: Duncker \& Humblot, 1974.

Schmitt, Carl. Political theology. Four chapters on the concept of soreveignty, trad. de George Schwab. Chicago: University of Chicago, 2005.

Schmitt, Carl. Staat, Großraum, Nomos. Arbeiten aus den Jahren 1916-1969. Hrsg. mit einem Vorwort und mit Anmerkungen versehen von Günter Maschke. Berlin: Duncker \& Humblot, 1995.

Schmitt, Carl. Teoría de la constitución, trad. de Francisco Ayala. Madrid: Alianza, 1982.

Secco, Lincoln, "As jornadas de junho", in: Cidades rebeldes. Passe livre e as manifestações que tomaram as ruas do Brasil, Ermínia Maricato et al. São Paulo: Boitempo, 2013, 71-78.

Serra, Teresa. La disobbedienza civile. Una risposta alla crisi della democrazia? Torino: Giappichelli, 2000.

Stavrakakis, Yannis, "La sociedad de la deuda. Grecia y el futuro de la posdemocracia", in: Posdemocracia, guerra monetaria y resistencia social en la Europa de hoy, Badiou et al. Madrid: Errata Naturae, 2015, 7-28.

Thoreau, Henry David, "Civil disobedience", in: A yankee in Canada, with anti-slavery and reform papers, Henry David Thoreau. Boston: Ticknor and Fields, 1866, 123-151, acedido em 12 de outubro de 2014, https://archive.org/stream/ yankeeincanada00thorrich\#page/n $7 /$ mode $/ 2$ up.

Valdecantos, Antonio. La excepción permanente o la construcción totalitaria del tiempo. Madrid: Díaz \& Ponz, 2014.

Varma, Vindra. Gandhi. Poder, parceria e resistência. São Paulo: Palas Athena, 2002.

Vitale, Ermanno. Defenderse del poder. Por una resistencia constitucional, trad. de Pedro Salazar Ugarte e Paula Sofía Vásquez Sánchez. Madrid: Trotta, 2010.

Wolin, Sheldon S. Democracy incorporated. Managed democracy and the specter of inverted totalitarianism. Princeton: Princeton University Press, 2010.

Zolo, Danilo, "Teoria e crítica do estado de direito", in: O estado de direito. História, teoria, crítica, orgs. Pietro Costa e Danilo Zolo. São Paulo: Martins Fontes, 2006, 3-94. 